\title{
HYDROGEOLOGIC DATA FROM A TEST WELL IN EAST-CENTRAL DUVAL COUNTY, FLORIDA
}

\section{U.S. GEOLOGICAL SURVEY}

Open-File Report 84-802

Prepared in cooperation with the

ST. JOHNS RIVER WATER MANAGEMENT DISTRICT and the CITY OF JACKSONVILLE, FLORIDA 


\section{CONVERSION FACTORS AND ABBREVIATIONS}

For those readers who may prefer to use metric units, conversion factors for terms used in this report are listed below:

Multiply

inch (in.)

foot $(f t)$

square foot $\left(f t^{2}\right)$

mile (mi)

gallon per minute (gal/min)

degree Fahrenheit $\left({ }^{\circ} \mathrm{F}\right)$

micromho per centimeter

at $25^{\circ}$ Celsius

(umho/cm at $25^{\circ} \mathrm{C}$ )
$\underline{B y}$

25.4

0.3048

0.09294

1.609

0.06309

${ }^{\circ} \mathrm{C}=5 / 9 \quad\left({ }^{\circ} \mathrm{F}-32\right)$

1.000
To obtain

millimeter (mm)

meter (m)

square meter $\left(\mathrm{m}^{2}\right)$

kilometer $(\mathrm{km})$

liter per second (L/s)

degree Celsius $\left({ }^{\circ} \mathrm{C}\right)$

microsiemens per centimeter

at $25^{\circ}$ Celsius

( $\mathrm{uS} / \mathrm{cm}$ at $25^{\circ} \mathrm{C}$ )

ADDITIONAL ABBREVIATIONS

$\mathrm{g} / \mathrm{cm}^{3}=$ gram per cubed centimeter

$\mathrm{mg} / \mathrm{L}=$ milligrams per liter 
HYDROGEOLOGIC DATA FROM A TEST WELL IN EAST-CENTRAL

DUVAL COUNTY, FLORIDA

By David P. Brown, U.S. Geological Survey,

Richard A. Johnson, St. Johns River Water Management District, and

Richard A. Broxton, U.S. Geological Survey

U.S. GEOLOGICAL SURVEY

Open-File Report 84-802

Prepared in cooperation with the

ST. JOHNS RIVER WATER MANAGEMENT DISTRICT and the

CITY OF JACKSONVILLE, FLORIDA

Tallahassee, Florida 
UNITED STATES DEPARTMENT OF THE INTERIOR

WILLIAM P. CLARK, Secretary

GEOLOGICAL SURVEY

Dallas L. Peck, Director

For additional information write to:

District Chief

U.S. Geological Survey, WRD Suite 3015

227 North Bronough Street Tallahassee, Florida 32301
Copies of this report can be purchased from:

Open-File Services Section Western Distribution Branch U.S. Geological Survey Box 25425, Federal Center Denver, Colorado 80225 (Telephone: (303) 236-7476) 
CONTENTS

Page

Abstract--_-_---_-_-_- 1

Introduction--_-_-_-_-_-_- 1

Purpose and scope-_-_-_-_-_- 1

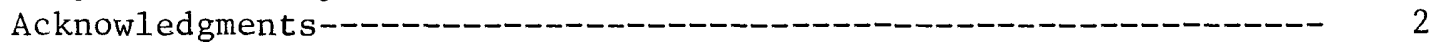

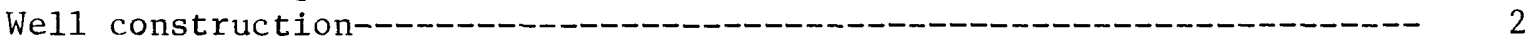

Geologic data--_-_-_-_-_- 5

Hydrologic data--------- 5

Water levels--_-_-_-_-_-_-_- 5

Artesian flow-_- 52

Water chemistry-_. 52

Selected references-_-_. 61

\section{ILLUSTRATIONS}

Page

Figure 1. Map showing location of test well-an- 3

2. Schematic diagram of well construction-_- 4

3. Diagram showing lithology at test well site--a---a-- 44

4. Electric log; long and short normal resistivity, and spontaneous potential-_-_ 45

5. Electric $\log$ (focused resistivity)- 45

6. Caliper and natural gamma log-a- 46

7. Neutron porosity log- 46

8. Gamma-gamma density log-a-n 47

9. Fluid resistivity log- 47

10. Temperature log- 48

11. Acoustic velocity log- 48

12-18. Graphs showing:

12. Water levels in drill stem and in annulus during drilling of test well-- 51

13. Artesian flow of test well during drilling-------- 53 


\section{ILLUSTRATIONS-- (Continued)}

\section{Page}

14. Flow-meter traverses in test well, open-hole interval 600 to 1,191 feet below land surface---- 54

15. Flow-meter traverses in test well, open-hole interval 600 to 1,570 feet below land surface---- 55

16. Flow-meter traverses in test wel1, open-hole interval 600 to 2,112 feet below land surface----

17. Specific conductance of water obtained from the drill stem and the annulus as the test well was drilled from 710 to 2,112 feet-_-_-_-_-_-_-_-_-

18. Chloride concentrations of water obtained from the drill stem and the annulus as the test well was drilled from 710 to 2,112 feet--_-_-_-----

\section{TABLES}

Page

Table 1. Lithologic log of test well-_-

2. Water levels in drill stem and in annulus during drilling of test well-_-_-

3. Specific conductance, chloride concentrations, and temperature of water obtained from the drill stem and the annulus as test well was drilled from 710 to

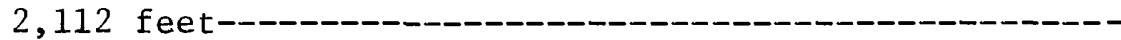




\section{HYDROGEOLOGIC DATA FROM A TEST WELL IN}

EAST-CENTRAL DUVAL COUNTY, FLORIDA

By David P. Brown, Richard A. Johnson, and Richard A. Broxton

\section{ABSTRACT}

A 2,112-foot test well was drilled in east-central Duval County, Florida, to obtain geologic, hydrologic, and water chemistry data. Drill cuttings and water samples were collected, and water-level measurements and lithologic and geophysical logs were made. The deposits to a depth of 575 feet consist of sand, clayey sand, phosphatic sandy clay, coquina, sandy limestone, and dolostone. Below 575 feet the deposits consist of fragmented and granular limestone, dolomitic limestone, and massive to finely crystalline dolostone, which comprise the Floridan aquifer system in the area.

Water levels were measured near or at the bottom of the drill hole through the drill stem and in the annular space between the drilled hole and drill stem at the well head as drilling progressed from 770 to 2,112 feet in depth. Water levels measured through the drill stem ranged from 1.17 feet above land surface at a depth of 2,107 feet to 15.0 feet above land surface at a depth of 1,574 feet. Water levels measured in the annular space ranged from 7.5 feet above land surface at a depth of 770 feet to 14.9 feet at various depths from 1,574 to 1,721 feet.

The flow of the test well was measured periodically with the drill stem in the hole during drilling. Flow ranged from about 250 gallons per minute at a depth of about 700 feet to about 2,200 gallons per minute at a depth of 2,112 feet. Maximum flow measured without the drill stem in hole was 3,000 gallons per minute.

Chloride concentrations of drill stem samples from a depth of 711 to 1,616 feet ranged from 22 to 172 milligrams per liter. Below 1,616 foot-depth, chlorides increased to as much as 818 milligrams per liter at 1,648 feet, varied between 345 and about 800 milligrams per liter from 1,648 feet to 2,071 feet, and reached a maximum of 5,450 milligrams per liter at 2,107 feet. Specific conductance changes are similar with depth. Water temperatures ranged from 25 to 28 degrees Celsius.

\section{INTRODUCTION}

\section{Purpose and Scope}

Little information is available on the geology, hydrology, and water chemistry of the deeper, saline-water zones of the Floridan aquifer system below a depth of 1,500 feet and the interconnection of these zones with the shallow freshwater zones in the northeast Florida area. Information on water levels, the location of the freshwater-saltwater interface, and on water chemistry is necessary to determine the relation between withdrawals of water from the freshwater zones and saltwater intrusion. The information will aid in assessing the availability of potable water from the Floridan aquifer system. 
The U.S. Geological Survey, in cooperation with the St. Johns River Water Management District and the City of Jacksonville, is investigating the hydrogeology and water chemistry of the deep zones of the Floridan aquifer system. An essential part of this investigation is the drilling, testing, and instrumentation of a network of five to seven deep test we1ls.

This report contains geologic, hydrologic, and water chemistry data collected during construction of a test well at the Arlington East Sewage facilities in east-central Duval County.

The well will be used to monitor ground-water levels and water chemistry. It will help determine the depth and change of position of the freshwatersaltwater interface.

\section{Acknowledgments}

The authors wish to express their appreciation to the Chairman, the Governing Board, and staff of the St. Johns River Water Management District, and to the Mayor, City Council, and staff of the City of Jacksonville for their support of this investigation. Particular acknowledgment is given to Douglas Munch, Director, Resource Evaluation Division, St. Johns River Water Management District, and to Gary Weise, Bio-Environmental Services, City of Jacksonville. The authors also wish to thank Allen Williams, Deputy Director (Water and Sewer), Mary Nogas and Pat Karney, Managing Engineers, and their staff, Department of Public Works, City of Jacksonville, for their help in locating the drill site for the test well and in the well construction.

\section{WELL CONSTRUCTION}

The location of the test well is shown in figure 1. Drilling took place from October 1982 to February 1983. As shown schematically in figure 2, the well was drilled to a depth of 2,112 feet. It was drilled to a depth of 600 feet by the standard mud-rotary method, cased with 14-inch diameter steel casing from land surface to a depth of $600 \mathrm{feet}$, and grouted from 600 feet to the surface. The remainder of the hole, 600 to 2,112 feet, was drilled by the reverse-air rotary method. A 75/8-inch diameter steel casing was installed from land surface to a depth of 2,050 feet and grouted from a depth of 2,050 feet to 1,640 feet. Construction on the well was suspended in August 1983, but is scheduled to be completed in 1984. This includes: (1) complete grouting of $75 / 8$-inch diameter steel casing from 1,640 feet to land surface, (2) drilling out cement plug inside 758 -diameter casing, and (3) drilling out temporary sandfill from 2,050 to 2,112 feet. After the well is completed, hydrologic tests will be made on the open-hole interval below a depth of 2,050 feet. 


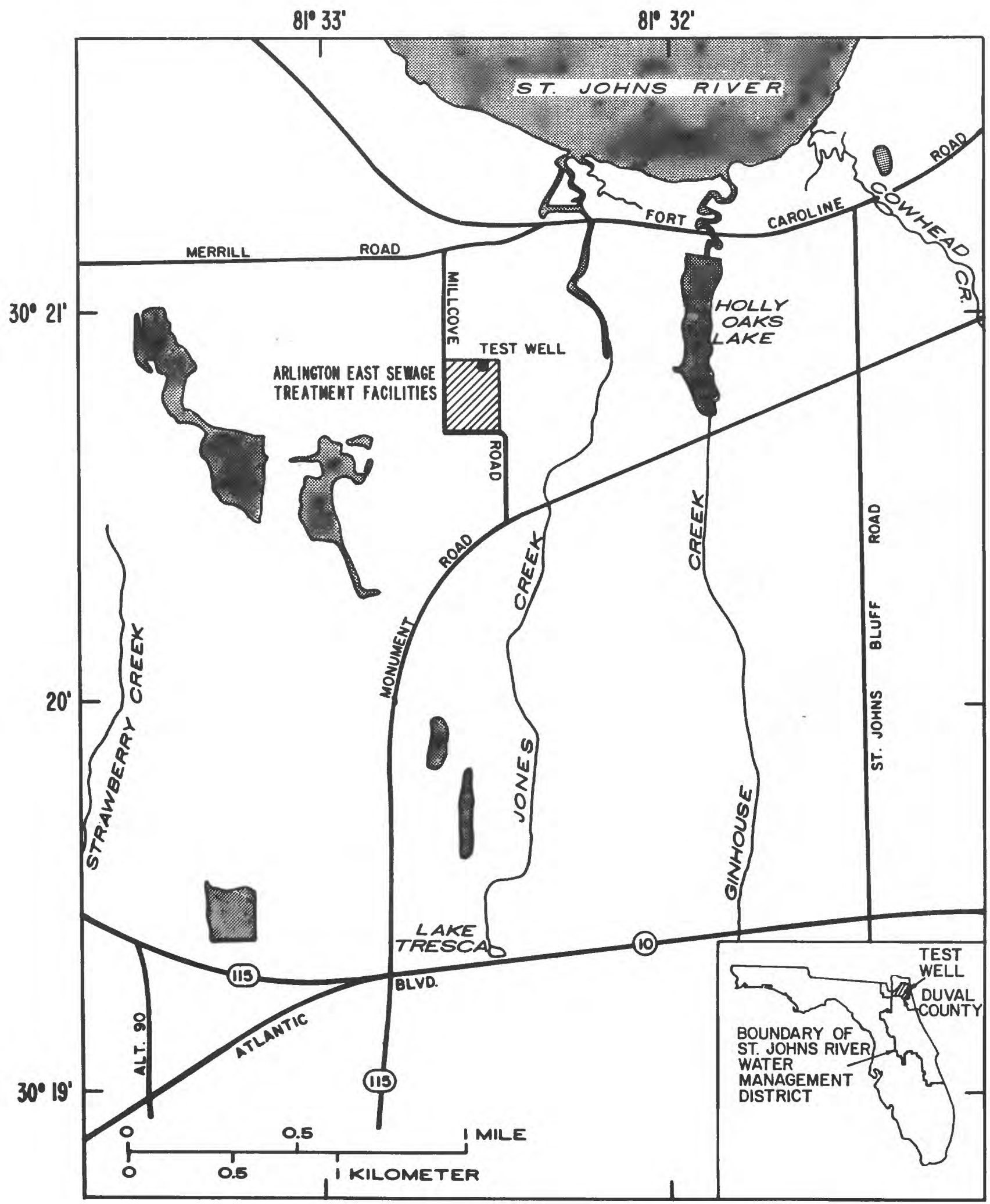

Figure 1.--Location of test well. 


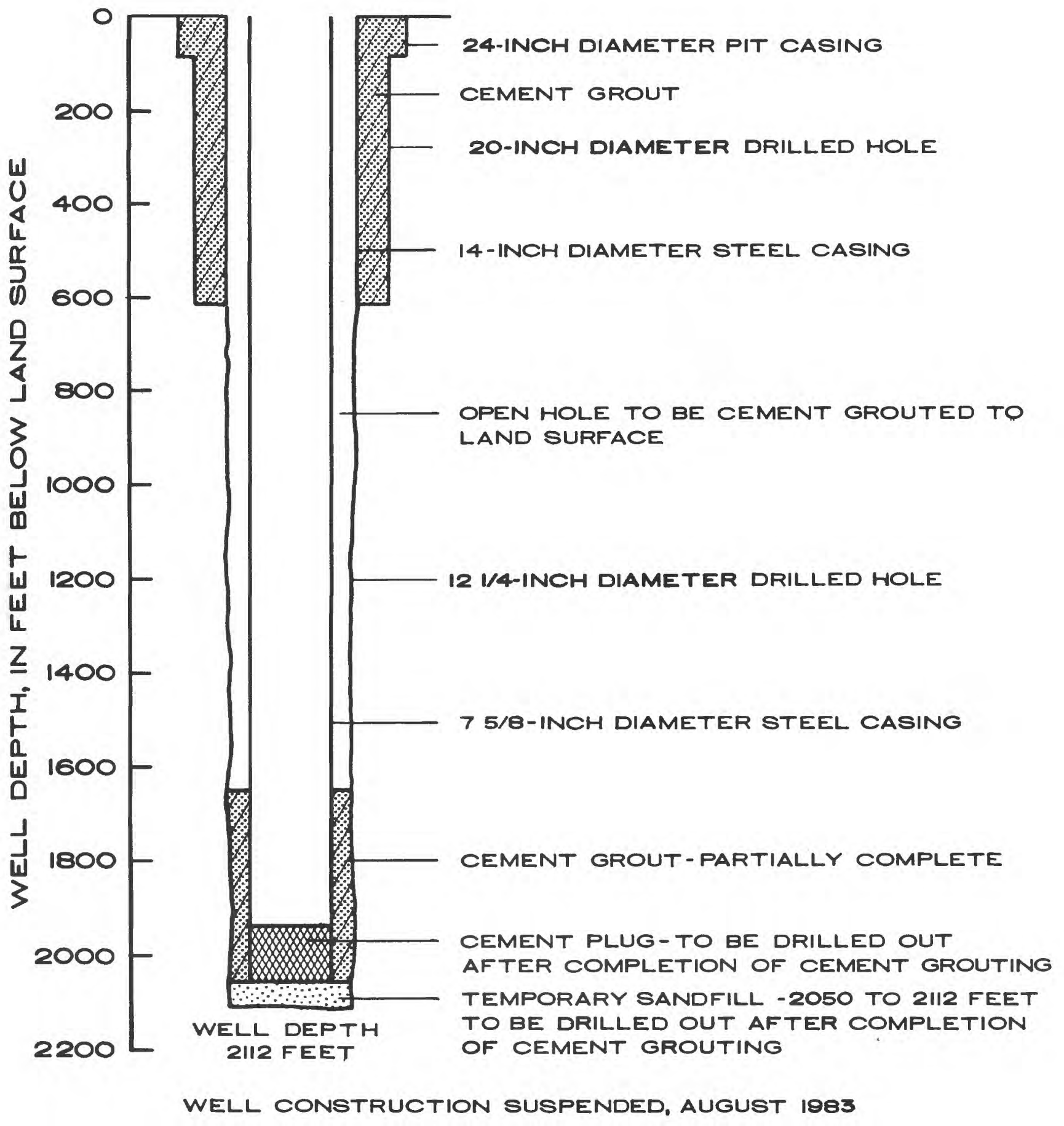

Figure 2.--Schematic diagram of well construction. 
Driil cuttings were collected at intervals of about $10 \mathrm{feet}$ and at changes in lithology (table 1). The deposits to a depth of 575 feet consist of sand, clayey sand, phosphatic sandy clay, coquina, sandy limestone, and dolostone (fig. 3). These materials range from Miocene (Hawthorn Formation) to Holocene in age. The deposits below 575 feet consist of fragmented and granular limestone, dolomitic limestone, and massive to finely crystalline dolostone of Paleocene to Eocene age. The formations, which comprise the Floridan aquifer system in northeast Florida according to Miller (1984), in ascending order, are the Cedar Keys Formation, Oldsmar Formation, Avon Park Formation, and Ocala Limestone.

Geophysical logs were made during construction of the well. Logs included in this report are electric (long and short normal resistivity, spontaneous potential, focused resistivity), caliper, natural gamma, neutron porosity, gamma-gamma density, fluid resistivity, temperature, and acoustic velocity (figs. 4-11).

\section{HYDROLOGIC DATA}

\section{Water Levels}

Water levels were measured in the drill stem near or at the bottom of the drill hole and in the annular space between the drilled hole and the drill stem as drilling progressed from 770 to 2,112 feet below land surface (table 2 and fig. 12). All water levels were above land surface and were measured in feet. The altitude of land surface at the test site was about 20 feet above sea level. Water-level data were not adjusted for density differences between freshwater and the mineralized water.

The water level or static head measured in the annulus or drill stem is the sum of the elevation head and the pressure head (Lohman and others, 1972). The pressure head depends on fluid density; thus, water-level measurements for wells containing salty water can be adjusted to equivalent freshwater heads in order to compare with the head in wells containing freshwater. Adjustments are made as described in Cooper and others, 1964, p. C28:

$$
1_{f}=\frac{p_{s}}{p_{f}} 1_{s}
$$

where $1_{f}=$ equivalent length of freshwater column;

$\mathrm{P}_{\mathrm{S}}=$ density of saltwater column;

$\mathrm{P}_{\mathrm{f}}=$ density of freshwater;

$1_{S}^{f}=$ measured length of saltwater column. 
Table 1. -- Lithologic log of test we11

Description $\quad \begin{gathered}\text { Thickness } \\ \text { (ft) }\end{gathered} \quad \begin{aligned} & \text { Depth to } \\ & \text { base (ft) }\end{aligned}$

Dolomitic limestone: brown, two types: (1) calcisiltite (recrystallized), composed of completely recrystallized pelecypod fragments by dolomite (silt size to very fine silt size), very high moldic porosity, scattered to some sand size silica (cloudy to clear, subrounded), some very fine silt size black phosphate grains, relatively hard but not crumbly due to high moldic porosity, (2) calcilutite, brown to gray, composed of chalky to very fine silt size dolomitic limestone cementing much silica sand and silt and scattered to some brown silt size dolomite, some to common very fine silt size to silt size black phosphate grains, very hard, no porosity

Dolos tone: two types: (1) gray-brown, calcilutite to calcisiltite, recrystallized, composed of completely recrystallized very fine grained dolomite and some fine silt size dark colored heavy mineral grains, some to common black fine silt size phosphate grains, scattered cloudy subrounded sand size silica grains, very hard, no moldic porosity, (2) do. as (1) above

Dolomitic limestone: three types: (1) light brown, calcarenite to calcisiltite, composed of completely recrystallized homogeneous clear calcite grains and brown dolomite moderately well cemented and many fine sand size to silt size silica grains, scattered to common very fine silt size to silt size black phosphate grains, scattered cloudy subrounded medium sand size silica grains, relatively hard but crumbly, not much porosity, (2) dolostone, brown, composed of completely recrystallized pelecypod fragments by dolomite (silt size to very fine silt size), very high to low moldic porosity, abundant to common sand size to silt size silica (cloudy to clear, subrounded), some $f$ ine sand size to very fine silt size black phosphate grains, (3) light gray, massive microcrystalline, containing some zones of common to abundant silt size silica and heavy mineral grains, abundant very fine silt size 
Table 1. -- Lithologic $\log$ of test we11... Continued

$\begin{array}{ccc}\text { Description } & \begin{array}{c}\text { Thickness } \\ (f t)\end{array} & \begin{array}{l}\text { Depth to } \\ \text { base (ft) }\end{array}\end{array}$

black phosphate grains, very hard, some small $z$ ones of moldic (pelecypod) porosity, scattered sand size cloudy subrounded silica grains

Limestone and dolostone: Limestone is white to light gray, calcilutite to very fine calcisiltite, recrystallized, composed of partially to completely recrystallized calcite, very hard, chalky, some to common silt size silica and heavy mineral grains, scattered medium sand size to very fine silt size black phosphate grains, some zones of very soft, very silty white chalk; dolos tone is brown to dark brown, calcisiltite to calcilutite, composed of completely recrystallized dolomite (silt size to very fine silt size), very high moldic porosity, very hard, many sand size to silt size clear to cloudy subrounded silica grains, scattered to some silt size to very fine silt size to occasional very fine sand size black phosphate grains

Dolostone: two types: (1) very dark gray to black calcisiltite to microcrystalline, composed of recrystallized dolomite cementing some to abundant silt size silica, heavy mineral and black silt size phosphate grains, (2) dark brown to brown, calcisiltite to calcarenite, composed of silt size to fine sand size dolomite cementing common to abundant silt size and fine sand size silica grains and some to common black silt size phosphate grains, hard, some small zones of fine moldic porosity, some small pebble size black phosphate grains

Dolos tone: do. (2) above

Dolostone: two types, do. (1) and (2), 120-130

Silt, sand and phosphate: silt and sand are brownish green, both dolomite and silica, (clear, subangular), unlithified and sof to moderately well lithified, many silt size to coarse sand size to small pebble size black phosphate grains
10

110

10

120

10

140

9

149

10

159 
Table 1. -- Lithologic log of test we11... Continued

\begin{tabular}{ccc} 
Description & $\begin{array}{c}\text { Thickness } \\
\text { ( } f t)\end{array}$ & $\begin{array}{l}\text { Depth to } \\
\text { base (ft) }\end{array}$ \\
\hline
\end{tabular}

Silt: green, dolomite, common to abundant silt size to very coarse sand size black phosphate grains, some silt size clear subangular silica

Silt: light gray, dolomite, moderately well Iithified, chalky, cementing some silt size silica and abundant black silt size to very coarse sand size to small pebble size phosphate grains

Silt: light greenish gray, dolomite, some to common silt size to sand size silica grains (cloudy, subrounded), many silt size to small pebble size black phosphate grains

Clay and silt: clay is white, kaolinite?, mixed with clay size dolomite grains, very soft; silt is do.; mainly clay

Silt, sand and phosphate: silt is green, dolomite and silica, many silt size to sand size black phosphate grains; sand is silica, subrounded, cloudy fine to coarse size; phosphate is black, very coarse sand to small pebble size, abundant

Silt, sand and phosphate: silt is gray-green, dolomite, some coarser silica and black phosphate grains; $s$ and is $f$ ine to very coarse, subrounded, cloudy, silica, very coarse

fraction is abundant; phosphate is black, sand size to small pebble size, abundant

Silt and phosphate: silt is green, do; phosphate is do.; some to scattered medium to coarse silica sand, do.

Silt, sand, phosphate and dolostone: silt, sand and phosphate are do; trace of dolostone: very dark gray, recrystallized and microcrystalline, very hard, silty (silica and phosphate), scattered sand (silica, subrounded, cloudy)

Silt and phosphate: green, silt is dolomite and silica, slightly sandy; phosphate is black, scattered to common, mainly coarse sand size grains; some coarse sand as do. 
Table 1. -- Lithologic log of test wel1... Continued

Description $\quad \begin{gathered}\text { Thickness } \\ \text { (ft) }\end{gathered} \quad \begin{gathered}\text { Depth to } \\ \text { base (ft) }\end{gathered}$

Silt: olive green, dolomite and silica, some to scattered sand and phosphate grains

Silt, sand and phosphate: green, do. 229-238 but greater proportion of silt, less coarse to medium sand

Silts tone, clays tone and dolostone: silts tone

is green, dolomite, some to common black

silt size phosphate grains, scattered fine

sand size silica (subrounded, cloudy),

relatively lithified; claystone is dark

green, some scattered silt size material as

silts tone components, occasional subrounded

cloudy sand size silica grain; dolostone is

trace, gray, very hard, microcrystalline,

very silty (predominantly phosphate and

heavy mineral grains)

Clays tone, sand, silt, phosphate and clay:

clays tone is do. but more silty; sand, silt

and phosphate are do. 229-238 but slightly

more silt in proportion to sand; clay is do.

189-199

Silt, sand and phosphate: do. 229-238

10

Silt, sand and phosphate: silt is gray-green to tan, dolomite, sandy and phosphatic (sand size

to silt size); sand is medium, silica, subrounded cloudy; phosphate is black, fine sand size to small pebble size; some silts tone-like material, tan relatively lithified

Dolostone, sand and phosphate: dolostone is white to $\tan$, calcisiltite, composed of very fine silt size homogeneous grains cementing much to some sand size and silt size silica, some moldic porosity, very scattered to scattered sand size black phosphate grains, very hard; sand is coarse, silica, subrounded, cloudy; phosphate is black, medium sand size to small pebble size, common to scattered; interval mainly dolostone: some very hard translucent amber euhedral to very hard milky microcrystalline dolostone 
Table 1. -- Lithologic $10 \mathrm{~g}$ of test we11... Continued

Silt, sand and phosphate: silt is gray-green

(slightly brownish), dolomite and silica;

sand is silica, subrounded, cloudy, fine to

coarse (dominantly medium); phosphate is

black fine sand size to very sinall pebble

size

Si1t, sand and phosphate: do. but sand is slightly coarser and phosphate is slightly finer grained, silt is lighter gray-brown

Silt, sand and phosphate: do. but greater proportion of silt, less of phosphate, sand and phosphate finer grained

Sand and phosphate: sand is cloudy, subrounded, silica, fine to medium coarse; phosphate is black medium sand size to coarse sand size; some gray-green silt

Silt, sand and phosphate: silt is gray-green, dolomite and silica; s and is silica, subrounded cloudy, fine to medium coarse; phosphate is black, dominantly medium sand size; some green clays tone (dolomite)

Silt and sand: silt is brownish green, mainly dolomite, very abundant; sand is silica, subrounded cloudy, fine to coarse; silt predominates 10

Silt, sand, phosphate and dolostone: silt is do.; $s$ and is silica, subrounded, cloudy, fine to coarse; phosphate is black, medium sand size to occasional coarse sand size; dolostone is trace, dark gray to tan to brown, composed of microcrystalline dolomite cementing very abundant fine sand size to silt size silica grains (cloudy, subrounded) and rounded black fine sand size phosphate grains, very hard

Silt, sand and phosphate: silt is dark green, mainly dolomite, very abundant; sand is silica, subrounded, cloudy, fine to medium; phosphate is black, fine sand size to medium sand size, relatively low proportion present 
Table 1. -- Lithologic log of test well...Continued

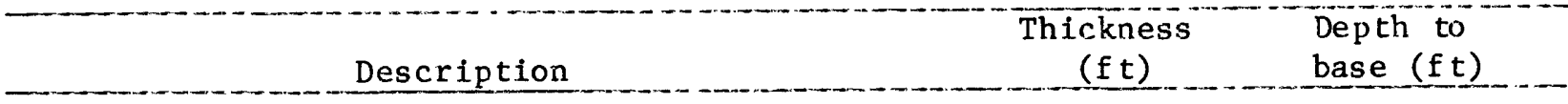

Silt and sand: silt is brown, dolomite, predominant; sand is silica, subrounded, cloudy, medium to medium coarse; some scattered phosphate

Silt: brown, dolomite and silica, occasional to some cloudy subrounded silica sand grains

Dolostone: brown to dark gray, calcisiltite to microcrystalline, composed of recrystallized dolomite (very fine silt size to microcrystalline) cementing common to very abundant silt size silica (subrounded, clear to cloudy) and silt size to occasional sand size black phosphate grains, very hard; scattered sand size silica (cloudy, subrounded)

Silt, phosphate and sand: silt is tan and greenish gray, dolomite, some silica, predominates; phosphate is silt size to small pebble size, black; sand is silica, fine to coarse but fine to medium fine predominates; interval is mainly silt

Silt, clays tone, phos phate and sand: silt is greenish-brown, dolomite, some silica, predominates; clays tone is dark to light green, dolomite, relatively hard and lithified, mainly relatively pure but some zones of silty material (silica and phosphate); phosphate is black, silt size to small pebble size; sand is fine to medium (some coarse), silica, subrounded, cloudy;

interval mainly silt and clays tone

Clays tone, dolostone, silt, sand and phosphate: clays tone is light green to greenish-brown, many very silty zones (silica and phosphate), relatively hard; dolos tone is two types: (1) brown, calcisiltite, composed of recrystallized dolomite crystals cementing some to common silt size silica (subrounded, cloudy) and silt size to occasional sand size black phosphate grains, very hard, some moldic porosity, occasional sand size silica grain (cloudy, subrounded), (2) light graybrown, microcrys talline, massive, zero porosity, very hard, no included grains; 
Table 1. -- Lithologic log of test well... Continued

\begin{tabular}{ccc} 
Description & $\begin{array}{c}\text { Thickness } \\
(f t)\end{array}$ & $\begin{array}{l}\text { Depth to } \\
\text { base (ft) }\end{array}$ \\
\hline
\end{tabular}

silt is green-brown, dolomite, some silica;

sand is fine to medium, silica, cloudy,

subrounded; phosphate is black, silt size to

coarse sand size

Silt, clays tone, sand and phosphate: do. but some coarse sand and some small pebble size phosphate

Dolostone, clays tone, silt, sand and phosphate: dolostone is $\tan$ to brown, calcisiltite to microcrystalline, composed of recrystallized dolomite cementing some to very abundant silt size silica (cloudy, subrounded) and silt size black phosphate grains, very hard, some moldic porosity, occasional sand size (subrounded, cloudy) silica and phosphate grains; clays tone, silt, sand and phosphate are do. but sand contains many coarse grains, clays tone contains less silt, relatively lithified

Dolos tone, silt, sand and phosphate: dolos tone is green-brown, calcilutite (shale-like), composed of recrystallized dolomite and some clay (?), very fine grained and homogeneous, shale-like fissility, very hard but partings break easily, pure (relatively) but contains scattered very fine silt size phosphate and other mineral grains; silt, sand and phosphate are do. but phosphate is silt size to coarse sand size; interval mainly dolostone

Dolostone, silt, sand and phosphate: do. but dolostone is also: (2) brown to dark gray, calcisiltite, composed of recrystallized dolomite cementing some silt size to sand size silica and phosphate grains, very hard;

interval predominantly dolos tone

Claystone, dolostone, silt, sand and phosphate: clays tone is light green to dark green-brown, dolomite, shale-like, some silica and phosphate grains (occasional sand size grain); dolostone, silt, sand and phosphate are do. 485-495; interval mainly claystone and dolos tone 
Table 1. -- Lithologic log of test wel1...Continued

\begin{tabular}{ccc} 
Description & $\begin{array}{c}\text { Thickness } \\
(\mathrm{ft} t)\end{array}$ & $\begin{array}{c}\text { Depth to } \\
\text { base (ft) }\end{array}$ \\
\hline
\end{tabular}

Silt, sand, claystone and phosphate: silt is brown, dolomite, predominates; sand is silica, subrounded, cloudy, fine to very coarse, much present; claystone is do. but with some dolostone; phosphate is black, scattered, medium sand size; interval predominantly silt and $s$ and

Claystone, silt, sand and phosphate: clays tone is brown to green-brown, dolomite, many silty zones, relatively hard, predominates; silt is do.; s and is do. but less fine to medium coarse present; phosphate is black, medium to coarse sand size

Dolostone and phosphate: dolostone is two types:

(1) gray, calcilutite to calcisiltite, composed of recrystallized dolomite cementing scattered to abundant very fine silt size silica and phosphate grains, very hard, occasional silt size grains, some very small zones of secondary porosity, some zones of euhedral dolomite crystals, (2) tan to white, microcrystalline, composed of completely recrystallized dolomite cementing scattered to some very fine silt size to occasional fine sand size silica and phosphate grains, silica grains are generally subrounded, cloudy, some to low moldic porosity, both types very hard; phosphate is black, coarse sand size to small pebble size, includes some heavy mineral grains

Dolostone: light brown, calcisiltite (recrystallized) composed of silt size dolomite rhombs, hard but crumbly (moderate secondary porosity), scattered silt size (subrounded, cloudy) silica, scattered to abundant very fine silt size black phosphate grains, very high moldic and secondary porosity

Claystone and silts tone: brown, relatively hard but crumbly, dolomite, relative homogeneous but some fine sand size and silt size phosphate and silica grains in both lithologies 
Table 1. -- Lithologic log of test wel1... Continued

Description $\quad \begin{gathered}\text { Thickness } \\ (f t)\end{gathered} \quad \begin{aligned} & \text { Depth to } \\ & \text { base (ft) }\end{aligned}$

Limestone, sand and dolostone: limestone is white to light gray, calcisiltite to calcirudite to microcrystalline, composed of recrystallized molluscan biohash cementing much fine sand size to silt size silica (clear, subrounded) and scattered black very

fine silt size to silt size phosphate grains, very hard, much moldic porosity; sand is silica, medium to coarse, cloudy to clear, subrounded; dolostone is tan to brown, calcisiltite (recrystallized), composed of recrystallized dolomite rhombs, hard but crumbly (much secondary porosity), scattered to some silt size to very coarse sand size silica grains (subrounded, cloudy), scattered to cormon black very fine silt size phosphate grains, high moldic porosity

Limestone: two types: (1) tan, calcisiltite to calcirudite, composed of partially recrystallized (outlines distinct to visible) forams and other biological debris cemented by generally recrystallized and hard calcite (microcrystalline to very fine silt size crystalline), high to moderate intergranular porosity, (2) do.

Limestone: do. (1) but tan to white, much more hard recrystallized calcite cement and less intergranular porosity

Limestone: $\tan$ to white, calcisiltite to calciru dite, composed of foram and other biological debris moderately to weakly cemented by fine silt size recrystallized calcite, grains relatively unaltered to partially recrystallized (outlines distinct)

Limes tone: white to light tan, calcisiltite to calcirudite, composed of partially recrystallized (outlines distinct) to relatively unal tered foram and other biological debris weakly to well cemented by recrystallized calcite: very fine cuttings

Limestone: white, calcisiltite to calcirudite, composed of partially recrystallized (outlines distinct) to unaltered foram and other biolog- 
Table 1. -- Lithologic log of test well... Continued

Description
recrystallized calcite, some moldic porosity,
much intergranular porosity

Thickness

Depth to

(ft)

base ( $f t$ )

Limestone: do. but some gray to grayish white limestone, more moderate to well cemented partially recrystallized zones

Limes tone: do. white

Limestone: do. but occasional zone of very well

$\frac{\text { Limes tone: }}{\text { cemented and completely recrystallized zero }}$ porosity limes tone

Limestone: two types: (1) do., (2) tan to very light brown, calcisiltite to calcarenite, composed of partially to completely recrystallized (outlines distinct) foram and other biological debris well cemented by recrystallized calcite, some porosity (integranular), possibly slightly dolomitic, relatively hard and not as crumbly as do.

Limestone: do. 741-750 but some scattered moldic porosity

Limestone: do. 741-750 but some less well cemented zones

Limestone: do. 741-750 but some massive completely recrystallized zones (grain boundaries less distinct: merely visible)

Limestone: do. $741-750$ but many massive completely recrystallized zones with some grain boundaries indistinct, low in tergranular porosity, very scattered moldic porosity

Limestone: do. 741-750 but less well cemer ted and less recrystallized

Limes tone: do. 779-789 but some calcirudite, some moldic porosity

Limes tone: do. 741-750

Limes tone: do. 741-750 but some moldic porosity 
Table 1. -- Lithologic log of test we11... Continued

\begin{tabular}{ccc} 
Description & $\begin{array}{c}\text { Thickness } \\
(\mathrm{ft})\end{array}$ & $\begin{array}{c}\text { Depth to } \\
\text { base (ft) }\end{array}$ \\
\hline
\end{tabular}

Peaty dolos tone and dolomitic limestone: peaty

dolostone is brown to light brown, calcisiltite

to microcrystalline, composed of very fine

grained completely recrystallized dolomite

crystals well cemented and very hard, some to

scattered black silt size to sand size peat

flecks, some sucrosic (rhombs and interrhombic

porosity) brown dolostone, some very small

vuggy ("pinspot") porosity and very roughly

outlined relict moldic porosity; dolomitic

limestone is light tan to very light brown, microcrystalline, very homogeneous and fine grained, massive, very hard, scattered silt size peat flecks, some vuggy porosity, scattered moldic porosity

Limes tone and peaty dolos tone: limestone is white to light gray, massive and microcrystalline and chalky (calcilutite) to some calcisiltite (recrystallized), homogeneous, very hard, some vuggy ("pinspot") porosity; peaty dolostone is brown and white, recrystallized, composed of completely recrystallized silt size to sand size dolomite rhombs (sucrosic) with scattered to abundant original material (white) forams in cement of dolomite rhombs, some foram moldic porosity, scattered to some black silt size peat flecks, very hard, scattered vuggy ("pinspot") porosity

Dolomitic limestone, limes tone and peaty dolos tone:

dolomitic limestone and peaty dolos tone are do. 839-849; limestone is gray and white, calcisiltite to calcarenite, composed of original material forams moderately well cemented by gray recrystallized calcite, moderately hard but somewhat crumbly, some intergranular and roughly outlined moldic porosity

Limestone and dolomitic limestone: 1 imes tone is light $\tan$ to very light brown, microcrystalline/massive (recrystallized) to chalky (calcilutite) to some mostly recrystallized calcisiltite, some vuggy ("pinspot") porosity, homogeneous, very hard, scattered black very fine silt size peat flecks; dolomitic lime$s$ tone is dark tan, microcrystalline (recrystallized), homogeneous, very hard, abundant large 
Table 1. -- Lithologic log of test we11... Continued

\begin{tabular}{llcl}
\hline & Description & $\begin{array}{c}\text { Thickness } \\
\text { (ft) }\end{array}$ & $\begin{array}{c}\text { Depth to } \\
\text { base (ft) }\end{array}$ \\
$\begin{array}{l}\text { recrystallized (dolomitic) forams, vuggy } \\
\text { porosity }\end{array}$ & 10 & 878
\end{tabular}

Dolomitic limestone: light brown to tan brown, microcrys talline/ recrystallized, composed of partially recrystallized (outlines distinct) foram and other biological debris well cemented by microcrystalline to silt size crystalline dolomite, some to abundant original material (white) forams, very hard, some foram moldic porosity and scattered vuggy porosity, many large forams present

Dolomitic limestone: brown, calcisiltite to calcarenite, composed of completely recrystallized grains weakly to moderately well cemented but crumbly, relatively high intergranular porosity, relatively homogeneous and fine grained, many large forams present

Limestone: dark tan, calcarenite to calcisiltite, composed of predominantly forams and some other biological material very weakly cemented and crumbly, somewhat dolomitic

Limestone: dark tan to tan, calcisiltite to calcarenite, composed of partially recrystallized to original material (predominantly) forams and some other biological debris moderately well cemented by recrystallized calcite, moderately hard and less crumbly than do., some foram outlines indistinct, moderate to high large foram content

Peaty dolomitic limestone: brown, calcisiltite to calcarenite (some calcirudite), composed of forams and other biological material partially to completely recrystallized (outlines distinct) and well cemented by recrystallized hard dolomitic calcite (microcrystalline and massive to silt size crystalline), occasional original material (white) foram occurs isolated in cement, hard, some to scattered black silt size peat flecks

Peaty dolomitic limes tone: grayish tan to gray, calcisiltite to calcarenite (some microcrystalline/massive), composed of original material 
Table 1. -- Lithologic log of test well...Continued

(white) to completely recrystallized (outlines distinct to visible) forans with scattered other biological debris very well cemented by recrystallized calcite (microcrystalline to sand size crystalline and euhedral) and dolomite (silt size rhombs), abundant to scattered peat present, very hard and massive, zero porosity

Peaty dolomitic limestone: do. but slightly more recrystallized and less original naterial (white) biological material, brownish tan

Peaty dolos tone, limestone and dolomitic limes tone: peaty dolos tone is dark brown, recrystallized, composed of fine to coarse silt size dolomite rhombs with scattered to some black peat flecks and common roughly outlined relict moldic and vuggy porosity, some original material (white) films lining foram moldic porosity, very hard; limestone is white to light gray, calcisiltite to calcirudite, composed of original material to partially recrystallized (outlines distinct) forams and other biological debris moderately well cemented to weakly cemented and relatively crumbly; dolomitic limestone is do. without peat

Limestone: grayish tan to gray, calcisiltite to calcirudite, composed of original material (white) to partially recrystallized (outlines distinct) to completely recrystallized (outlines distinct) foram and other biological debris well cemented by hard microcrystalline to silt size recrystallized calcite (possibly slightly dolomitic)

Dolomitic limestone: brown to light brown, ca1cisiltite to occasional calcirudite, composed of completely recrystallized (outlines faintly visible) forams and other biological debris in cement of hard recrystallized dolomite or dolomitic calcite with some to abundant original material (white) forams scattered and isolated in cement, occasional black flecks of peat, some zones of high moldic porosity 
Table 1. -- Lithologic log of test well... Continued

\begin{tabular}{ccc} 
Description & $\begin{array}{c}\text { Thickness } \\
(f t)\end{array}$ & $\begin{array}{c}\text { Depth to } \\
\text { base (f } t)\end{array}$ \\
\hline
\end{tabular}

Limestone: grayish white to tan, calcisiltite to calcirudite, composed of completely recrystallized (outlines indistinct to occasionally distinct) foram and other biological debris well cemented by very hard microcrystalline recrystallized calcite, very hard, low vuggy porosity

Dolomitic limestone: grayish tan, calcisiltite to calcarenite, composed of partially to completely recrystallized (outlines distinct) forams and other biological debris with some to abundant original material (white) forams cemented by very hard microcrystalline recrystallized cenent, very hard, low porosity

Dolomitic limestone: tan to light brown, calcisiltite to calcirudite with some zones of microcrystalline recrystallized material, composed of original material (white) to complete1y recrystallized (outlines distinct) forams and other biological material well cemented by very hard silt size recrystallized cement, some moldic porosity, very hard, some zones of recrystallized grains with indistinct outlines

Dolomitic limestone: two types: (1) brown calcirudite to calcarenite, composed of completely recrystallized (outlines very distinct) foram and other biological debris moderately to well cemented (but not much cement visible: high intergranular porosity) by very fine silt size recrystallized cement, hard, scattered to occasional original material (white) film on inside of foram moldic porosity, (2) grayishtan, calcisiltite to recrystallized microcrystalline, composed of completely recrystallized (outlines indistinct) foram and other biological debris well cemented by recrystallized hard cement, common zones of distinctly bounded partially recrystallized grains

Limestone: tan, calcirudite to calcarenite, composed almost exclusively of large weakly cemented whole cone shaped forams and other smaller forams, high intergranular porosity 
Table 1. -- Lithologic log of test well... Continued

\begin{tabular}{ccc} 
Description & $\begin{array}{c}\text { Thickness } \\
(f t)\end{array}$ & $\begin{array}{l}\text { Depth to } \\
\text { base (ft) }\end{array}$ \\
\hline
\end{tabular}

Limestone: white to light gray, calcilutite to calcirudite, composed of original material to partially recrystallized (outlines distinct) foram and other biological debris in chalky to silt size relatively soft and unrecrystallized cement, moderate to high moldic porosity, some cryptocrystalline gray homogeneous limestone

Limestone: 1ight grayish tan, calcisiltite, composed of completely recrystallized foram and other biological debris (outlines distinct) cemented by silt size crystalline cement, hard, moderate (foram) moldic porosity, some zones of visible grain boundaries

Dolomitic limestone: tan, calcisiltite to calcirudite, composed of completely recrystallized (outlines visible to indistinct) foram and other biological debris well cemented by microcrystalline to very fine silt size crystalline cement, hard, some moldic porosity

Dolomitic limestone: tan to very light brown, calcisiltite to calcarenite, composed of partially to completely recrystallized (outlines visible to indistinct) foram and other biological debris well cemented by recrystallized microcrystalline to very fine silt size crystalline cement, some zones of original material (white) grains, very hard, low porosity

Dolomitic limestone: brown, calcisiltite to calcirudite to microcrystalline, composed of completely recrystallized massive microcrystalline dolomite and some calcite cementing scattered to common original material (white) forams, very hard, low porosity

Limestone: grayish $\tan$, calcisiltite to calcirudite, composed of completely recrystallized (outlines distinct to visible) foram and other biological debris moderately to well cemented by silt size recrystallized to microcrystalline cement, relatively hard, some foram moldic porosity 
Table 1. -- Lithologic log of test we11... Continued

\begin{tabular}{ccc} 
Description & $\begin{array}{c}\text { Thickness } \\
(f t)\end{array}$ & $\begin{array}{l}\text { Depth to } \\
\text { base (ft) }\end{array}$ \\
\hline
\end{tabular}

Limestone: light tan, calcirudite to calcisiltite, composed of weakly cemented original material cone shaped forams, very small echinoids and some other biological debris, cement is chalky, soft and relatively unrecrystallized

Dolomitic limestone and peat: dolomitic limestone is two types: (1) light tan to light brown, calcisiltite to calcirudite, composed of original material (white) forams and other biological debris well cemented by silt size recrystallized to microcrystalline cement (dolomitic calcite to dolomite), hard, some massive recrystallized zones, low porosity, (2) dark gray-brown speckled with white, calcisiltite to calcirudite, composed of abundant mainly very fine original material (white) biological debris cemented by dark colored very fine silt size recrystallized dolomite, some roughly outlined moldic porosity, some to scattered disseminated peat; peat is very dark brown, laminated, up to small pebble size fragments, contains carbonate material and black silt size phosphate (?) grains in termixed

Peaty dolomitic limestone: gray-brown, calcisiltite to calcarenite (scattered calcirudite), composed of original material (white) to completely recrystallized (outlines distinct) to completely recrystallized (outlines ind istinct) forams and other biological debris well cemented by silt size recrystallized to microcrystalline dolomite cement, some to common black peat flecks and large particles, hard, low porosity

Dolomitic limestone: tan to light brown, calcisiltite to calcirudite, composed of partially to completely recrystallized (outlines visible to indistinct) forams and other biological debris well cemented by silt size recrystallized to microcrystalline cement, very hard, scattered small zones of original material (white) fragments, cement predominantly dolomite, low porosity 
Table 1. -- Lithologic log of test well...Continued

Description $\quad \begin{gathered}\text { Thickness } \\ \text { (ft) }\end{gathered}$ bepth to $(\mathrm{ft})$

Limestone: light tan, calcisiltite to microcrystalline, composed of completely recrystallized biological debris (outines ind istinct) cemented by microcrystalline to silt size recrystal1 ized cement, hard, veins of translucent yellow calcite cenent outlining some grains, grain outlines sometimes slightly visible, some vuggy and moldic porosity with euhedral calcite crystal infilling, slightly dolomitic, appears relatively homogeneous and chalky

Limes tone: light to dark tan, calcisiltite to calcirudite, composed of weakly cemented original material to partially recrystallized large to small forams, small echinoids and other biological debris, relatively high intergranular porosity, cenent is silt size recrystallized grains, scattered rough1y outlined moldic porosity

Limestone and dolostone: limestone is do. 112030 , but more $\tan s i l t$ size recrystaliized cement, more grain boundaries visible, more dolomitic, greater moldic porosity; dolostone is brown, completely recrystallized and homogeneous, very fine grained (very fine silt size to microcrystalline), very hard, similar to brown chert in hand specimen appearance

Dolostone: dark brown to brown, recrystallized, composed of euhedral dolomite rhombs silt size to very fine sand size (sucrosic), scattered roughly outlined relict moldic porosity, very hard, very homogeneous and pure lithologically

Dolos tone: very dark gray-brown, recrystallized, composed of euhedral dolomite rhombs (silt size to very fine sand size), some vuggy ("pinspot") porosity, very hard, scattered light colored areas of translucent rhombs

Dolomitic limestone: $\tan$ to light brown, calcisiltite to calcarenite, composed of partially to completely recrystallized (outlines visible to distinct) foram and other biological debris well cemented by recrystallized silt size to microcrystalline cement, hard, scattered zones of original material (white) 
Table 1. -- Lithologic log of test we11... Continued

\begin{tabular}{|c|c|c|}
\hline Description & $\begin{array}{l}\text { Thickness } \\
\text { (f } t)\end{array}$ & $\begin{array}{l}\text { Depth to } \\
\text { base ( } t)\end{array}$ \\
\hline $\begin{array}{l}\text { fragments, cement predominantly dolomite, low } \\
\text { porosity }\end{array}$ & 10 & 1181 \\
\hline $\begin{array}{l}\text { Dolomitic limestone: tan to light brown, cal- } \\
\text { cisiltite to calcirudite, composed of weakly } \\
\text { to moderately well cenented completely recrys- } \\
\text { tallized (outlines distinct) forams and other } \\
\text { biological debris, cement is silt size recrys- } \\
\text { tallized and mainly dolomite, somewhat } \\
\text { crumbly, moderate intergranular and roughly } \\
\text { outlined moldic porosity }\end{array}$ & 10 & 1191 \\
\hline $\begin{array}{l}\text { Limestone: } 1 \text { ight brown, calcisiltite to calcare- } \\
\text { nite, composed of completely recrystallized } \\
\text { (outlines distinct) Eoram and other biological } \\
\text { debris weakly to moderately well cemented by } \\
\text { silt size recrystallized dolomite cement, high } \\
\text { intergranular and roughly outlined moldic } \\
\text { porosity, relatively crumbly }\end{array}$ & 10 & 1203 \\
\hline $\begin{array}{l}\text { Limestone: light gray-tan, calcilutite to cal- } \\
\text { cirudite (recrystallized), composed of com- } \\
\text { pletely recrystallized (microcrystalline) } \\
\text { material, hard, very high moldic porosity, } \\
\text { some grains dissolved and replaced by poro- } \\
\text { sity, some grains completely replaced } \\
\text { (outlines indistinct) by microcrystalline } \\
\text { recrystallized calcite, well cemented }\end{array}$ & 10 & 1213 \\
\hline $\begin{array}{l}\text { Limestone: white to light tan, calcisiltite to } \\
\text { calcirudite, composed of completely recrystal- } \\
\text { lized (outlines distinct) foram and other } \\
\text { biological debris weakly to moderately well } \\
\text { cemented by silt size recrystallized calcite, } \\
\text { many loose (replaced) forams in cuttings, } \\
\text { somewhat crumbly }\end{array}$ & 11 & 1224 \\
\hline $\begin{array}{l}\text { Limestone: light gray-tan, calcisiltite to cal- } \\
\text { cirudite (recrystallized), composed of com- } \\
\text { pletely recrystallized (outlines distinct) } \\
\text { forams and other biological debris weakly } \\
\text { cemented by euhedral silt size to fine sand } \\
\text { size calcite crystals, very crumbly, some } \\
\text { original material (white) forams and films } \\
\text { present, high intergranular porosity }\end{array}$ & 10 & 1234 \\
\hline
\end{tabular}


Table 1. -- Lithologic log of test well... Continued

\begin{tabular}{ccc}
\hline Description & $\begin{array}{c}\text { Thickness } \\
\text { ( } \mathrm{f} t)\end{array}$ & $\begin{array}{l}\text { Depth to } \\
\text { base (ft) }\end{array}$ \\
\hline
\end{tabular}

Limestone: do. but grains are finer (no calcirudite) and cenent is finer: microcrystalline to very fine silt size crystalline

Limestone: light gray-tan, calcisiltite (recrystallized), composed of completely recrystallized (outlines ind istinct) biological material cemented by microcrystalline hard calcite, low foran moldic porosity, hard

Limestone: very light brown, calcisiltite to calcirudite (recrystallized), composed of completely recrystallized (outlines distinct to visible) foram and other biological debris in cement of microcrystalline to silt size recrystallized calcite, moderately well cemented to crumbly, some massive microcrystalline zones with grain boundaries indistinct, hard to crumbly, moderate to low intergranular and moldic porosity

Dolostone and limestone/dolostone: dolostone is dark brown, recrystallized, composed of euhedral rhombs of recrystallized dolomite (silt size to sand size) very hard, low to some moldic porosity (lined with euhedral crystals); limestone/dolostone is an intimate combination of both of the following lithologies and all gradations between: limes tone is tan to light brown, calcisiltite to calcarenite (recrystallized), composed of completely recrystallized (outlines visible to indistinct) foram and other biological debris well cemented by microcrys talline calcite (possibly dolomitic), low relict moldic porosity; dolostone is light brown to brown, recrystallized, composed of euhedral rhombs (sand size to microcrystalline) of dolomite, very hard, some very roughly outlined relict moldic porosity and vuggy porosity

Dolos tone: dark brown to brown to mottled dark gray, recrystallized, composed of completely recrystallized dolomite rhombs well cemented, very hard, some very roughly outlined relict moldic or vuggy porosity, some sucrosic brown dolostone with relatively high interrhombic porosity 
Table 1. -- Lithologic log of test well... Continued

\begin{tabular}{ccc}
\hline Description & $\begin{array}{c}\text { Thickness } \\
\text { (ft } t)\end{array}$ & $\begin{array}{l}\text { Depth to } \\
\text { base (ft) }\end{array}$ \\
\hline
\end{tabular}

Dolos tone: brown to light brown, recrystallized, composed of euhedral dolomite rhombs (exclusively silt size) well cemented and very hard, some light brown fine grained sucrosic dolo$s$ tone (high vuggy, interrhombic and relict moldic porosity)

Dolostone/dolomitic limestone: brown and dark gray mottled to tan, recrystallized, composed of intimate combinations and gradations of: dolostone: composed of silt size to occasional fine sand size euhedral dolomite rhombs well cemented and hard, some roughly outlined relict moldic porosity, and dolomitic limestone: composed of completely recrystallized microcrystalline dolomitic calcite, very hard, homogeneous, only scattered very rough grain outlines visible, scattered isolated dolomite rhomb in microcrystalline cement

Dolomitic limestone: grayish tan, calcisiltite to calcarenite (recrystallized), composed of completely recrystallized microcrystalline (grain outlines indistinct to visible) dolomitic calcite cementing abundant to scattered euhedral dolomite rhombs (brown to light brown, silt size to very fine sand size)

Dolomitic limestone: tan and gray mottled, calcirudite to calcarenite (recrystallized), composed of completely recrystallized (outlines distinct) foram and other biological debris moderately well cemented but crumbly, high to moderate intergranular porosity, many loose foram and other biological materials in cuttings

Dolos tone: brown to dark brown to dark brown and dark gray mottled, recrystallized, composed of euhedral dolomite rhombs well cemented and very hard (silt size to very fine sand size), scattered to common tan completely recrystallized (outlines distinct) isolated grains of foram and other biological debris (dolomitic limestone), some to scattered very roughly outlined relict moldic porosity 
Table 1. -- Lithologic log of test well...Continued

\begin{tabular}{ccc} 
Description & $\begin{array}{c}\text { Thickness } \\
(\mathrm{ft} t)\end{array}$ & $\begin{array}{l}\text { Depth to } \\
\text { base (ft) }\end{array}$ \\
\hline
\end{tabular}

Dolostone: very dark brown to black, recrystallized, composed of very fine silt size euhedral dolomite, very hard, generally massive, very low porosity, some brown small finely sucrosic zones (moderate relict moldic and vuggy porosity)

Dolostone: dark gray mottled with brown and light tan, calcirudite to calcisiltite (recrystallized), composed of completely recrystal1 ized very fine silt size (gray) dolomite rhombs (very hard and massive and very low porosity) with scattered to common zones of brown silt size to fine sand size euhedral dolomite rhombs with moderate interrhombic (sucrosic) porosity and common to abundant isolated grains of completely recrystallized (tan dolomitic calcite) foram and other biological material (outlines distinct)

Dolostone: dark brown, recrystallized, composed of very fine silt size to silt size euhedral dolomite rhombs, very hard, some vuggy/interrhombic porosity, very scattered to some tan dolomitic calcite grains of forams and other biological debris (silt size to sand size) isolated in cement of rhombs

Peaty dolomitic limestone: gray to tan, calcisiltite to calcirudite (recrystallized), composed of completely recrystallized (outlines distinct to indistinct) foram and other biological debris well cemented by microcrystalline recrystallized cement, hard, scattered to common original material (white) biological material grains isolated in cement, some moldic porosity lined with euhedral crystals, scattered to abundant very fine silt size to silt size peat flecks

Glauconitic pyritic limestone: gray and white and light tan, calcirudite to calcisiltite and recrystallized, composed of completely recrystallized microcrystalline rubbly limes tone material and white recrystallized biological material (outlines distinct) cemented by gray microcrystalline calcite with many stringers, veinlets and flecks or pieces of dark green 
Table 1. -- Lithologic log of test well... Continued

\begin{tabular}{ccc} 
Description & $\begin{array}{c}\text { Thickness } \\
(\mathrm{ft} t)\end{array}$ & $\begin{array}{l}\text { Depth to } \\
\text { base (ft) }\end{array}$ \\
\hline
\end{tabular}

glauconite, chalcopyrite, pyrite and other dark colored fine grained impurities, very hard, banded in appearance, scattered vuggy porosity lined with euhedral dolomite

Limes tone: gray-tan and white, calcirudite (very coarse), composed of very coarse (small pebble size) completely recrystallized (outlines distinct) microcrystalline biological material well cemented by gray microcrystalline calcite, hard, low to moderate intergranular and moldic porosity

Dolostone: dark gray, recrystallized, composed of silt size euhedral dolomite rhombs, well cemented and very hard, very scattered to some white original material (?) biological material isolated in dolomite (rhombs) cement, some moldic porosity

Limestone: gray and white, calcisiltite to (predominantly) calcirudite (do. 1388-1398 but less recrystallized), composed of predominantly very coarse white to light gray biological material with some silt size to sand size material completely recrystallized (outlines distinct) moderately to well cemented by gray recrystallized calcite and partially to completely recrystallized silt size to fine sand size biological material grains (outlines indistinct to visible), moderately hard, some intergranular moldic (?) porosity

Limestone: dark gray and white, calcisiltite to calcirudite, do. but more dark gray calcite cement, some pyrite, some to scattered isolated dolomite rhombs in cement, hard to modera tely hard

Glauconitic 1imestone: do. 1378-1388 but not banded, more speckled and some silt size recrystallized calcite as cement, less pyrite and glauconite

Limestone: tan and gray, calcisiltite to calcirudite (recrystallized), composed of completely recrystallized (outlines ind istinct) biological material (microcrystalline) well 
Table 1. -- Lithologic log of test well... Continued

\begin{tabular}{ccc} 
Description & Thickness & $\begin{array}{c}\text { Depth to } \\
\text { base (ft) }\end{array}$ \\
\hline
\end{tabular}

cemented by very hard microcrystalline (gray) calcite ceinent, scattered pyrite and glauconite, very hard, very scattered original material (white) remains of isolated forams or biological material fragments, slightly dolomitic, probably zero porosity

Dolomitic limestone and dolostone: dolomitic

limes tone is gray and light gray to tan, calcirudite to calcisiltite (recrystallized), composed of completely recrystallized (outlines distinct to indistinct) biological debris well cemented by very fine silt size to microcrystalline recrystallized gray cement, hard, scattered pyrite and moldic porosity, more calcic than dolomitic; dolostone is medium gray, recrystallized, composed of silt size euhedral dolomite rhombs well cemented and very hard, homogeneous except for small areas of dolomitic limes tone lithology incorporated, zero porosity

Dolostone and dolomitic limestone: dolostone is do. but no small areas of dolomitic limes tone; dolomitic limestone is gray and $\tan$ to white, calcirudite to calcisiltite, composed of completely recrystallized (outlines distinct) biological debris moderately to well cemented by gray calcite and some dolomite (silt size, recrystallized), moderate to low intergranular porosity

Dolomitic limestone: do. but less gray cement and less recrystallized

Dolostone and dolomitic limestone: dolostone is gray to dark gray, recrystallized, composed of silt size euhedral dolomite rhombs well cemented and very hard, low or zero porosity; dolomitic limestone is do. 1461-1472 but cement is also fine sand size rhombs, outlines of grains sometimes indistinct, slightly more recrystallized

Dolostone: very dark gray and medium gray, recrystallized, composed exclusively of fine sand size and silt size euhedral dolomite rhombs relatively loosely cemented and with 
Table 1. -- Lithologic log of test well... Continued

\begin{tabular}{ccc} 
Description & $\begin{array}{c}\text { Thickness } \\
(f t)\end{array}$ & $\begin{array}{c}\text { Depth to } \\
\text { base (ft) }\end{array}$ \\
\hline
\end{tabular}

high interrhombic porosity (sucrosic), brittle, very dark gray material contains pyrite (?)

Dolostone and limestone: dolostone is dark gray to gray, recrystallized, composed of euhedral dolomite rhombs (silt size) well cemented and hard, very low porosity (some small zones of sucrosic/vuggy porosity); limestone is white, calcilutite to calcisiltite, composed of very fine grained recrys tallized homogeneous calcite, "chalk"; dolostone predominates

Dolostone: light gray to brownish gray, recrystallized, composed of euhedral silt size dolomite rhombs, very hard and well cemented, very homogeneous but some grain boundaries are visible (only macroscopically), zero porosity

Dolostone: do. but no grain boundaries visible, completely homogeneous and very hard

Dolos tone: grayish dark brown, recrystallized, composed of euhedral silt size dolomite rhombs well cemented and very hard, some zones of very fine sand size rhombs and moderate relict moldic porosity (?), common to scattered moldic porosity, scattered original material (white) calcic fragments, low to moderate porosity overall

Dolostone: dark brown, recrystallized, composed of silt size euhedral dolomite rhombs well cemented and very hard, some zones of low irregular (vuggy?) porosity and light brown color and slightly coarser rhomb size, scattered small and irregular white isolated original material zones

Dolostone: grayish dark brown, recrystallized, composed of silt size to microcrystalline dolomite rhombs well cemented and very hard, zero porosity, very homogeneous, a few small zones of slightly coarser grained rhombs which appear sucrosic macroscopically

Dolostone: two types: (1) do. (2) brown, recrystallized, composed of silt size euhedral 
Table 1. -- Lithologic log of test well... Continued

\begin{tabular}{ccc} 
Description & $\begin{array}{c}\text { Thickness } \\
\text { (ft) }\end{array}$ & $\begin{array}{c}\text { Depth to } \\
\text { base (f } t)\end{array}$ \\
\hline
\end{tabular}

dolomite rhombs less well cemented with irregular interrhombic porosity, sucrosic appearing

Dolostone and limestone: dolostone is brown and white, recrystallized, composed of silt size euhedral dolomite rhombs well cemented and very hard with common to abundant relatively unaltered (white to $\tan$ ) isolated biological debris fragments in the cement, scattered pyrite flecks; limestone is tan to light brown, calcisiltite (recrystallized), composed of completely recrystallized (grain outlines visible to indistinct) biological debris well cemented by silt size to some microcrystalline hard cement, probably very low porosity, scattered isolated dolomite rhombs in cement also

Dolostone: light brown-tan to very dark brown to black, recrystallized, composed of silt size euhedral dolomite rhombs well cemented and very hard, relatively homogeneous (some very rough relict grain outlines visible macroscopically only), some zones of slightly coarser grained rhombs and moderate interrhombic (sucrosic) porosity, darker colored dolostone contains much disseminated very fine grained pyrite (?)

Dolostone and peaty dolostone: dolostone is grayish brown, recrystallized, composed of silt size euhedral dolomite rhombs very well cemented and relatively massive with scattered to some vuggy porosity, scattered silt size peat flecks, very hard; peaty dolostone is dark brown, recrystallized, composed of coarse silt size to fine sand size completely recrystallized euhedral dolomite rhombs well cemented with high secondary porosity (sucrosic) and common to abundant very fine silt size to silt size black peat flecks, hard

Dolostone: grayish brown, recrystallized, composed of silt size euhedral dolomite rhombs very well cemented and very hard/massive, very little to zero porosity, homogeneous, scattered to very scattered peat flecks 
Table 1. -- Lithologic log of test well... Continued

\begin{tabular}{ccc} 
Description & $\begin{array}{c}\text { Thickness } \\
(\mathrm{ft} t)\end{array}$ & $\begin{array}{c}\text { Depth to } \\
\text { base (ft) }\end{array}$ \\
\hline
\end{tabular}

Dolostone: two types: (1) brown, recrystallized, composed of completely recrystallized coarse

silt size to very fine sand size euhedral dolomite rhombs well cemented but with very high secondary (interrhombic) and relict moldic (sucrosic) porosity, rhorabs very clean and reflective, hard, rather pure with only very scattered peat flecks, (2) do.

Dolos tone: do. 1606 - 1616 but more brown less gray

Dolostone: light brownish gray to light brown, recrystallized, composed of fine silt size to silt size euhedral dolomite rhombs well cemented but with high secondary (interrhombic) and relict moldic (sucrosic) porosity resembles pumice in texture and low specific gravity, some former grain outlines visible, scattered peat flecks

Dolomitic limestone and dolostone: dolomitic limestone is $\tan$, calcisiltite to calcarenite, composed of completely recrystallized (outlines visible to indistinct) foram and other biological debris well cemented by very hard very fine silt size recrystallized to microcrystalline recrystallized cement, some small zones of euhedral silt size to fine sand size light brown dolomite rhombs, some very roughly outlined relict foram moldic porosity, scattered silt size peat flecks, somewhat massive; dolos tone is dark brown, recrystallized, composed of completely recrystallized euhedral silt size to fine sand size dolomite rhombs well cementing common to abundant tan dolomitic calcite in the form of completely recrystallized (outlines distinct) isolated grains of forams and other biological debris, very hard, low secondary porosity

Dolomitic limestone and dolostone: dolomitic limes tone is tan to light brown, do. but much more dolomitic with abundant zones of euhedral dolomite rhombs; dolos tone is do. 1638-1648 
Table 1. -- Lithologic log of test wel1... Continued

Description

Thickness

Depth to

$(\mathrm{ft})$

base ( $f t$ )

Dolostone: very light brown and tan (mottled), recrystallized, composed of an intimate mixture of euhedral dolomite rhombs (very fine silt size) and tan calcic very fine silt size to microcrystalline dolomite, scattered peat (?) flecks, massive, very low porosity, former grain boundaries indistinct except where grain now completely surrounded by euhedral dolomite rhombs (light brown); some dolostone as do. 1638-1648

Dolomitic limestone: tan, calcisiltite to calcirudite, composed of completely recrystallized (outlines distinct to visible) foram and other biological debris well cemented by microcrystalline to very fine silt size recrystallized cement, very hard, some secondary and foram moldic porosity, scattered peat (?) flecks

Dolomitic limestone: tan, calcisiltite, composed of completely recrystallized (outlines distinct to visible) very fine grained forams (predominantly) and other biological debris well cemented by very fine silt size recrystallized hard cement, scattered isolated dolomite rhombs, scattered peat (?) flecks, low to some roughly outlined moldic and foram porosity, generally less dolomitic than do.

Limestone: tan, calcisiltite to calcarenite, composed of completely recrystallized (outlines distinct to visible) foram and other biological debris well cemented by very fine silt size recrystallized cement, hard, somewhat dolomitic, some small zones of microcrystalline cement, very scattered peat (?) flecks, some roughly outlined moldic and foram moldic porosity

Dolostone and quartz: dolostone is three types: (1) dark brown, recrystallized, composed of very fine silt size to microcrystalline dolomite rhombs, very hard, some very roughly outlined relict moldic porosity but generally massive and pure, scattered sucrosic zones, (2) dark gray and white (mottled), calcirudite (recrystallized), composed of completely re- 
Table 1. -- Lithologic log of test we11...C Continued

\begin{tabular}{ccc}
\hline Description & $\begin{array}{c}\text { Thickness } \\
(f t)\end{array}$ & $\begin{array}{l}\text { Depth to } \\
\text { base ( } t)\end{array}$ \\
\hline
\end{tabular}

crystallized (outlines distinct to visible) white biological debris well cemented by dark gray to brownish gray very fine silt size to microcrystalline dolomite, very hard, some moldic porosity, some zones of massive microcrystalline gray to light gray recrystallized dolomite, (3) do. 1668-1678; quartz is milky, euhedral, pebble size particles and crystals; brown dolostone and quartz predominate

Dolostone, 1 imestone and quartz: dolostone is

two types: (1) dark gray to gray to graybrown, recrystallized, composed of very fine silt size to microcrystalline recrystallized dolomite cementing completely recrystallized (outlines indistinct, lighter colored) grains, very hard very well cemented, mottled in macroscopic appearance, some moldic porosity, (2) brown, recrystallized composed of silt size euhedral dolomite rhombs well cemented but with moderate secondary (interrhombic) porosity (sucrosic), hard, relatively pure, some very roughly outlined relict moldic porosity; limestone is white, calcilutite to calcisiltite, composed of completely recrystallized (outlines ind istinct) biological debris, very homogeneous appears to be "chalk" but is relatively hard; quartz is milky, euhedral, much finer crystal size than do.

Limestone: light greenish tan, calcilutite, composed of very homogeneous, chalky calcite, soft, possibly clayey

Dolomitic limestone and peaty dolos tone: dolomitic limestone is very light gray, calcilutite to calcisiltite (calcilutite predominates), composed of relatively homogeneous very fine dolomitic limestone grains with scattered outlines of biological fragments visible, moderately hard, chalky, scattered silt size heavy mineral (?) grains; peaty dolostone is two types (1) dark brown to brown, recrystallized, composed of silt size recrystallized dolomite rhombs and scattered to some peat flecks (silt size), very hard, some moldic porosity, (2) do. \#1, 1721-1731 
Table 1. -- Lithologic log of test well... Continued

\begin{tabular}{ccc} 
Description & $\begin{array}{c}\text { Thickness } \\
\text { (ft) }\end{array}$ & $\begin{array}{l}\text { Depth to } \\
\text { base (ft) }\end{array}$ \\
\hline
\end{tabular}

Glauconitic dolostone and glauconitic dolomitic

limestone: glauconitic dolostone is light

brownish gray, calcilutite to calcisiltite

(recrystallized), composed of completely re-

crystallized euhedral silt size light brown

dolomite rhombs cementing abundant glauconite

(silt size to small pebble size) and much

intermixed very fine silt size to chalky

homogeneous very 1 ight gray dolomite, hard;

glauconitic dolomitic limestone is light

greenish gray, calcilutite to calcisiltite, composed of very homogeneous very fine silt

size to clay size dolomitic limestone grains, chalky, zero porosity, scattered to common

very fine silt size glauconite, moderately

hard to soft

Glauconitic dolostone and pyrite: glauconitic dolostone is grayish brown, recrys tallized, composed of euhedral dolomite rhombs ( $f$ ine silt size) with no porosity, scattered to common silt size glauconite, very hard, scattered zones of chalky light gray dolomite, very hard; pyrite is abundant to common, massive to euhedral

Glauconitic dolomitic limestone, dolostone and quartz: glauconitic dolomitic limestone is light grayish $\tan$, calcisiltite to calcirudite (recrystallized), composed of completely recrystallized (outlines visible to indistinct) biological debris well cemented by very fine silt size to microcrystalline recrystallized cement in which are isolated silt size dolomite rhombs and silt size to coarse sand size glauconite grains, very hard, slightly chalky in appearance; dolostone is two types: (1) brown to dark brown, recrystallized, composed of recrystallized euhedral dolomite rhombs (microcrystalline to fine sand size), very hard, microcrystalline homogeneous and massive to coarser sucrosic high secondary (interrhombic) porosity, scattered peat flecks, (2) dark gray and gray, recrystallized, composed of silt size to microcrystalline dolomite rhombs, massive to sucrosic (high in terrhombic secondary porosity) cementing light gray biological grains (completely recrystallized, 
Table 1. -- Lithologic $\log$ of test we11... Continued

\begin{tabular}{ccc} 
Description & $\begin{array}{c}\text { Thickness } \\
\text { ( } f t)\end{array}$ & $\begin{array}{c}\text { Depth to } \\
\text { base (ft) }\end{array}$ \\
\hline
\end{tabular}

outlines generally visible), very hard, some secondary and moldic (?) porosity; quartz is milky, subhedral some to common

Glauconitic limestone, dolostone and quartz:

glauconitic limestone is white to grayish tan, calcilutite to calcisiltite (recrystallized), composed of microcrystalline to chalky to very fine silt size crystalline relatively ind istinct grains cementing much very fine silt size to medium sand size glauconite, some former grains slightly visible, very hard, chalky material intimately intersperced with recrystallized material; dolostone is dark gray and light gray-brown mottled, recrystallized, composed of completely recrystallized microcrystalline to very fine silt size crystalline dolomite, lighter colored areas are former grains, darker is cement, very hard, relatively homogeneous at $10 \mathrm{X}$, scattered moldic (?) porosity; quartz is milky, subhedral, some to common

Glauconitic dolomitic limestone, chert, quartz and dolos tone: glauconitic dolomitic limestone is white to light gray, calcilutite to calcirudite (recrystallized), composed of completely recrystallized biological debris (outlines indistinct) and abundant to common silt size to fine sand size glauconite grains well cemented by microcrystalline to very fine silt size crystalline cement and much interspersed chalky material, very hard, probably not much porosity; chert is translucent to opaque, green-brown to dark gray, abundant; quartz is milky to clear, euhedral to subhedral to massive, crystals generally sand size, common to abundant; dolos tone is dark brown and dark gray, recrystallized, composed of euhedral very fine silt size to coarse silt size dolomite rhombs well cemented and very hard, scattered peat (?) flecks, massive to slightly sucrosic, dolostone is minor constituent of interval

Chert, glauconitic limestone and quartz: chert is dark brown to gray to tan (mottled), translucent to opaque, very abundant; glauconitic 
Table 1. -- Lithologic log of test we11...Continued

\begin{tabular}{ccc} 
Description & $\begin{array}{c}\text { Thickness } \\
\text { (ft) }\end{array}$ & $\begin{array}{l}\text { Depth to } \\
\text { base (ft) }\end{array}$ \\
\hline
\end{tabular}

limestone is light brown to white, calcilutite to calcisiltite (recrystallized), composed of completely recrystallized homogeneous calcite grains with chalky material intimately intersperced cementing common silt size to fine sand size glauconite grains, very hard, some dolomitic (rhombs) zones and chalk; quartz is milky, massive to subhedral, some to common

Glauconitic limestone: tan to light gray, calcilutite to calcirudite (recrys tallized), composed of completely recrystallized biological grains (outlines distinct) and much intersperced chalky material and much in tersperced glauconite (very fine silt size to medium sand size), very hard, some roughly outlined moldic porosity, some dolomitic zones (rhombs), some microcrystalline zones relatively free of chalky material

Glauconitic dolomitic limestone and chert: glauconitic dolomitic limestone is light gray to light brown, calcilutite to calcisiltite (recrystallized), composed of completely recrystallized homogeneous calcite and rhombic dolomite with abundant silt size to fine sand size glauconite, some relict biological grain boundaries visible, very hard, abundant intersperced chalky material, some zones of brown dolomite rhombs; chert is tan to light gray, some dark brown present, abundant

Glauconitic limestone, dolos tone and quartz: glauconitic limes tone is light gray and green s peckled, recrystallized microcrystalline, composed of completely recrystallized calcite (microcrystalline and chalky) with no grain boundaries visible cementing very abundant silt size to fine sand size glauconite, very hard, scattered pyrite, scattered moldic porosity; dolostone is dark gray, recrystallized, composed of very fine silt size to microcrysta11 ine recrystallized dolomite with some lighter gray very roughly outlined relict biological grains visible macroscopically only, very hard, low moldic or vuggy porosity; quartz is milky, subhedral to euhedral, some to common 
Table 1. -- Lithologic log of test well... Continued

\begin{tabular}{ccc}
\hline Description & $\begin{array}{c}\text { Thickness } \\
(\mathrm{ft} t)\end{array}$ & $\begin{array}{l}\text { Depth to } \\
\text { base (ft) }\end{array}$ \\
\hline
\end{tabular}

Glauconitic limestone and dolostone: galuconitic

1 imes tone is very light gray, recrys tallized, composed of completely recrystallized calcite (grain boundaries indistinct) cementing scattered to common very fine silt size to silt size glauconite grains, very hard, zero porosity, some intersperced chalky material; dolostone is two types: (1) brown to dark brown, recrystallized, composed of very fine silt size to fine sand size euhedral dolomite rhombs, sucrosic to massive, very scattered to common zones of tan dolomitic calcite as very fine grained material representing recrystallized biological grains in dolomite rhomb cement, scattered peat flecks, very hard, some secondary porosity, (2) medium gray, massive, microcrystalline, composed of very scattered very fine silt size light gray dolomite grains in dark gray microcrystalline dolomite cement, very hard but platy or flaky, some very fine silt size glauconite (?), zero porosity; interval predominantly glauconitic limestone

Glauconitic dolomitic limestone: $\tan$ and light gray, microcrys talline recrys tallized, composed of completely recrystallized (outlines indistinct) biological material (very hard and microcrystalline) with some to common chalky material intersperced throughout, scattered to common silt size glauconite grains, very hard, probably low porosity, scattered pyrite

Glauconitic dolomitic limestone: do. but more glauconite, grain boundaries less ind istinct, no pyrite

Dolomitic limestone: tan, recrystallized to calcisiltite to calcarenite, composed of predominantly completely recrystallized microcrystalline (outlines indistinct) to completely recrystallized (outlines visible) dolomitic calcite in the form of relict biological debris with some intersperced hard chalky material, very hard, scattered glaucon$i$ te, scattered foram moldic porosity with 
Table 1. -- Lithologic log of test well...Continued

Dolomitic limestone and dolostone: dolomitic

limes tone is light brownish-gray, recrys tal-

lized, composed of completely recrystallized microcrystalline dolomitic limestone with relict biological material grains occasionally slightly visible, scattered to common intersperced chalky material, very hard, possibly low porosity, very scattered glauconite; dolo$s$ tone is brown, recrystallized, composed of fine silt size to silt size euhedral dolomite rhombs and scattered to common white calcic material in the form of isolated biological grains with boundaries distinct agains $t$ background of euhedral dolomite rhomb cement, very hard, massive but common zones of sucrosic dolostone (silt size to fine sand size euhedral rhombs with relatively high secondary porosity), scattered peat flecks, scattered relict moldic porosity

Limestone and dolostone: 1imes tone is gray and tan, calcarenite to calisiltite, composed of original material (?) to partially recrystallized (outlines distinct) foram and other biological debris moderately well cemented (but crumbly) by light gray silt size cement, relatively high intergranular porosity, scattered massive recrystallized zones and dolomitic zones, scattered glauconite; dolostone is two types: (1) light brown to tan, recrystallized, microcrystalline with much intersperced calcic chalky material, very hard, scattered peat and pyrite, zero porosity, occasional completely recrystallized (outlines distinct) relict foram grain, (2) very dark gray and gray, recrystallized, composed of silt size euhedral dolomite rhombs (sucrosic) with very high secondary porosity, hard and well cemented but because of high porosity: crumbly, possibly pyritic

Dolomitic limestone: tan, recrystallized, composed of completely recrystallized (outlines ind istinct to slightly visible) biological debris in the form of very fine silt size grains, relatively homogeneous, hard, some intersperced hard chalky material, low to some vuggy porosity 
Table 1. -- Lithologic log of test we11... Continued

Description $\quad \begin{gathered}\text { Thickness } \\ \text { ( } f t)\end{gathered} \quad \begin{aligned} & \text { Depth to } \\ & \text { base (ft) }\end{aligned}$

Limestone: $\tan$, calcisiltite to calcarenite, composed of completely recrystallized (outlines distinct) foram and other biological debris well to moderately well cemented by very fine silt size cement, hard, grains recrystallized by very fine silt size material also, moderate relict moldic and secondary porosity

Dolomitic limestone: tan, calcisiltite to recrystallized, composed of silt size to sand size completely recrystallized (outlines visible to indistinct) biological material cemented by hard microcrystalline to chalky to very fine silt size crystalline calcite with abundant isolated euhedral dolomite rhombs, hard, low secondary porosity

Dolomitic limestone: 1ight brown, recrystallized, composed of completely recrystallized (outlines indistinct to distinct) biological debris moderately to well cemented by hard silt size to microcrystalline calcite and euhderal dolomite rhomb cement, low secondary porosity

Dolomitic limestone: 1ight brown and tan, recrystallized, composed of some completely recrystallized (outlines distinct) biological debris (sand size to small pebble size) grains cemented by abundant light brown very fine silt size euhedral dolomite rhombs and tan hard chalky calcite, low secondary and relict moldic porosity, hard, common isolated euhedral dolomite rhombs in chalky calcite

Dolos tone: dark gray-brown, recrystallized, composed of very fine silt size to silt size euhedral dolomite rhombs, very hard and well cemented with abundant finely sucrosic zones and moderate to high relict moldic porosity

Dolostone and dolomitic limestone: dolostone is three types: (1) brown, recrys tallized, composed of fine silt size euhedral rhombs to microcrystalline relatively homogeneous and massive, very hard, low vuggy porosity, (2) 
Table 1. -- Lithologic log of test well...Continued

\begin{tabular}{ccc} 
Description & $\begin{array}{c}\text { Thickness } \\
(f t)\end{array}$ & $\begin{array}{l}\text { Depth to } \\
\text { base (ft) }\end{array}$ \\
\hline
\end{tabular}

light brown, recrystallized, composed of coarse silt size to fine silt size euhedral dolomite rhombs with high secondary porosity, sucrosic, hard, (3) light brownish gray, recrystallized, composed of very fine silt size euhedral dolomite rhombs, massive, very hard, zero porosity, scattered to common silt size euhedral dolomite rhombs isolated in cement; dolomitic limestone is tan and gray, calcisiltite to calcirudite (recrystallized), composed of completely recrystallized (outlines visible to indistinct) biological debris (recrystallized by microcrystalline to very fine silt size material) moderately to well cemented by very fine silt size to microcrystalline cementsome relict moldic and secondary porosity; dolomitic limestone is minor constituent of in terval

Dolostone: brownish gray to gray, recrystallized, composed of very fine silt size euhedral dolomite rhombs, very hard, predominantly massive and homogeneous with scattered finely sucrosic zones (silt size rhombs), some to common very fine secondary porosity

Dolostone: three types: (1) dark brown, recrystallized, composed of silt size euhedral dolomite rhombs, very hard, massive and homogeneous, very low vuggy porosity, (2) gray, recrystallized, composed of very fine silt size to microcrystalline euhedral dolomite rhombs, very low to some vuggy porosity (lined with silt size euhedral dolomite rhombs), very hard, homogeneous and massive but "platy", (3) brown, recrystallized, composed of silt size euhedral dolomite rhombs with very high secondary porosity and finely sucrosic, hard but crumbly due to porosity

Dolos tone: very dark gray to brown to $\tan$ as end members and mottled transitions, recrystallized, microcrystalline and very fine silt size euhedral dolomite rhombs (especially in brown dolostone), massive and very hard, very scattered vuggy porosity lined with silt size euhedral dolomite rhombs, generally very mot- 
Table 1. -- Lithologic log of test wel1... Continued

\begin{tabular}{cccc}
\hline Description & $\begin{array}{c}\text { Thickness } \\
(f t)\end{array}$ & $\begin{array}{l}\text { Depth to } \\
\text { base ( } f t)\end{array}$ \\
\hline
\end{tabular}

tled speckled and veined, some finely sucrosic high secondary porosity zones

Dolos tone: brown, recrystallized, composed of silt size to very fine silt size to microcrystalline euhedral dolomite rhombs very well cemented and very hard, massive, homogeneous, very scattered fine vuggy porosity

Dolomitic limes tone: tan to light brown, recrystallized, composed of completely recrystallized (outlines indistinct to visible) biological debris and hard recrystallized cement (as very fine silt size euhedral dolomite rhombs and chalky hard calcite), grain outlines visible in hand specimen but very uniform and recrystallized at $10 \mathrm{X}$

Dolomitic limestone and dolostone: dolomitic limestone is light tan, recrystallized, composed of completely recrystallized (outlines indistinct to visible) biological debris (grains silt size to fine sand size, recrystallized by fine silt size euhedral dolomite rhombs) well cemented by hard chalky calcite and fine silt size euhedral dolomite rhombs, very hard, low intergranular/vuggy? porosity; dolos tone is do. 2009-2019

Dolomitic limestone: light brown speckled tan, recrystallized, composed of completely recrystallized biological grains (outlines distinct, replaced by hard chalky calcite, silt size to sand size) in cement of very hard chalky calcite and many very fine silt size euhedral dolomite rhombs, very low porosity

Dolomitic limestone: tan to light brown, recrystallized, composed of very hard homogeneous mixture of hard chalky calcite material and very fine silt size euhedral dolomite rhombs (former grain boundaries indistinct)

Dolomitic limestone and dolostone: dolomitic

1 imestone is tan and gray speckled white, recrystallized, composed of completely recrystallized (outlines indistinct) biological debris (silt size, recrystallized by very fine 
Table 1. -- Lithologic log of test well... Con tinued

\begin{tabular}{|c|c|c|}
\hline Description & $\begin{array}{c}\text { Thickness } \\
\text { (ft) }\end{array}$ & $\begin{array}{l}\text { Depth to } \\
\text { base ( } f t)\end{array}$ \\
\hline
\end{tabular}

silt size to microcrystalline material) well cemented by hard chalky to very fine silt size to microcrystalline material, generally homogeneous and hard, some zones of high chalky material (white) content; dolostone is two types; (1) gray to very dark gray, recrystallized, composed of microcrystalline to very fine silt size euhedral dolomite rhombs, very hard, very homogeneous (at $10 \mathrm{X}$ ), some finely sucrosic zones, scattered relict moldic porosity, (2) brown to dark brown, recrystallized, composed of very fine silt size to silt size euhedral dolomite rhombs and some to common chalky tan dolomitic calcite, well to weakly cemented; some microcrystalline dolomite

Dolomitic limestone and dolostone: dolomitic limes tone is do. but white and light gray, finer grained and more microcrystalline material, harder, some to moderate relict moldic and secondary porosity, some grain outlines distinct (white chalky material); dolostone is light brown to brown to greenbrown to gray to dark gray, recrystallized, composed of euhedral dolomite rhombs (very fine silt size to silt size to fine sand size) weakly (crumbly) to moderately well cemented, predominantly sucrosic to massive, relatively diverse-appearing in texture and color

Dolostone and dolomitic limestone: dolostone is two types: (1) dark grayish brown, recrystallized, composed of very fine silt size euhedral dolomite rhombs, very homogeneous, very hard, zero porosity, (2) brown, recrystallized, composed of silt size to very fine silt size euhedral dolomite rhombs with relatively high secondary porosity (sucrosic), homogeneous, moderately well to well cemented, hard; dolostone is light brown and tan, recrystallized, composed of intimate mixtures of euhedral silt size light brown dolomite rhombs and tan chalky calcic material, very uniform at $10 \mathrm{x}$, no grain boundaries visible, hard, probably zero porosity 2091
Dolostone: light gray-brown to very dark graybrown, recrystallized, composed of completely

.


Table 1. -- Lithologic log of test well...Continued

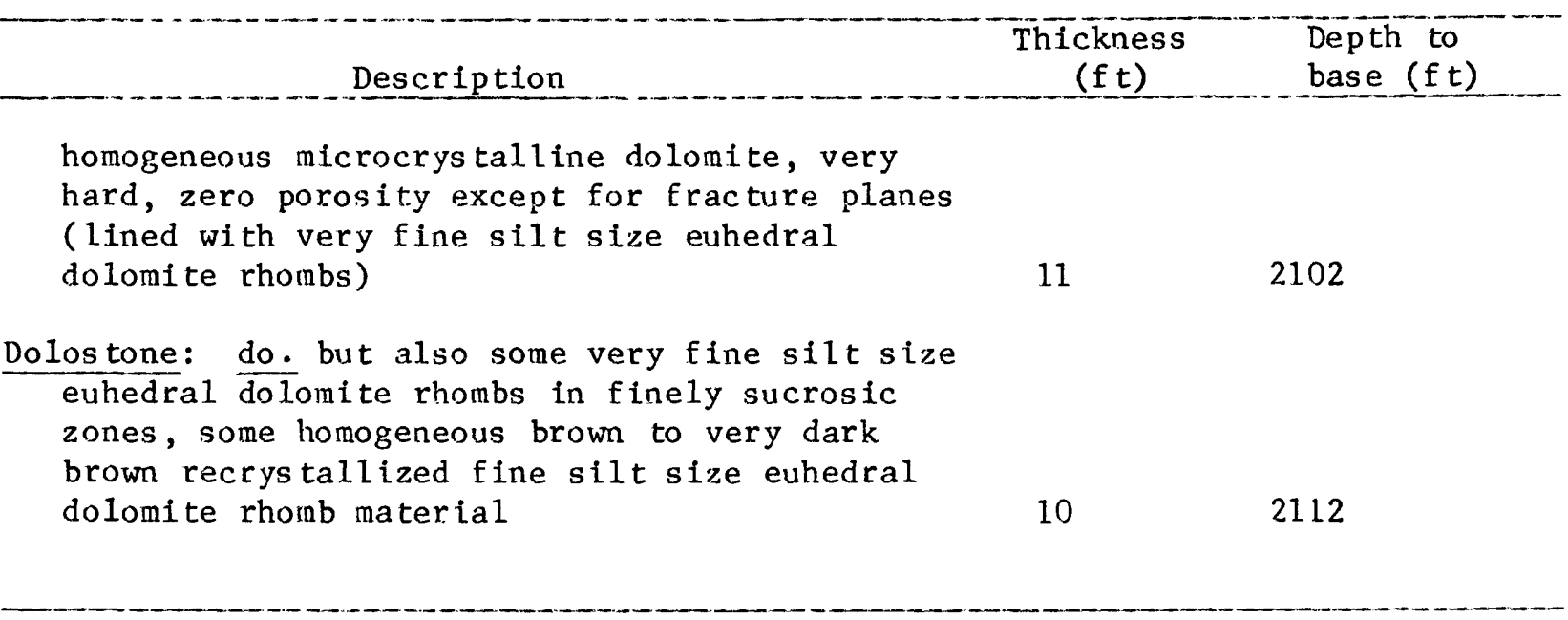




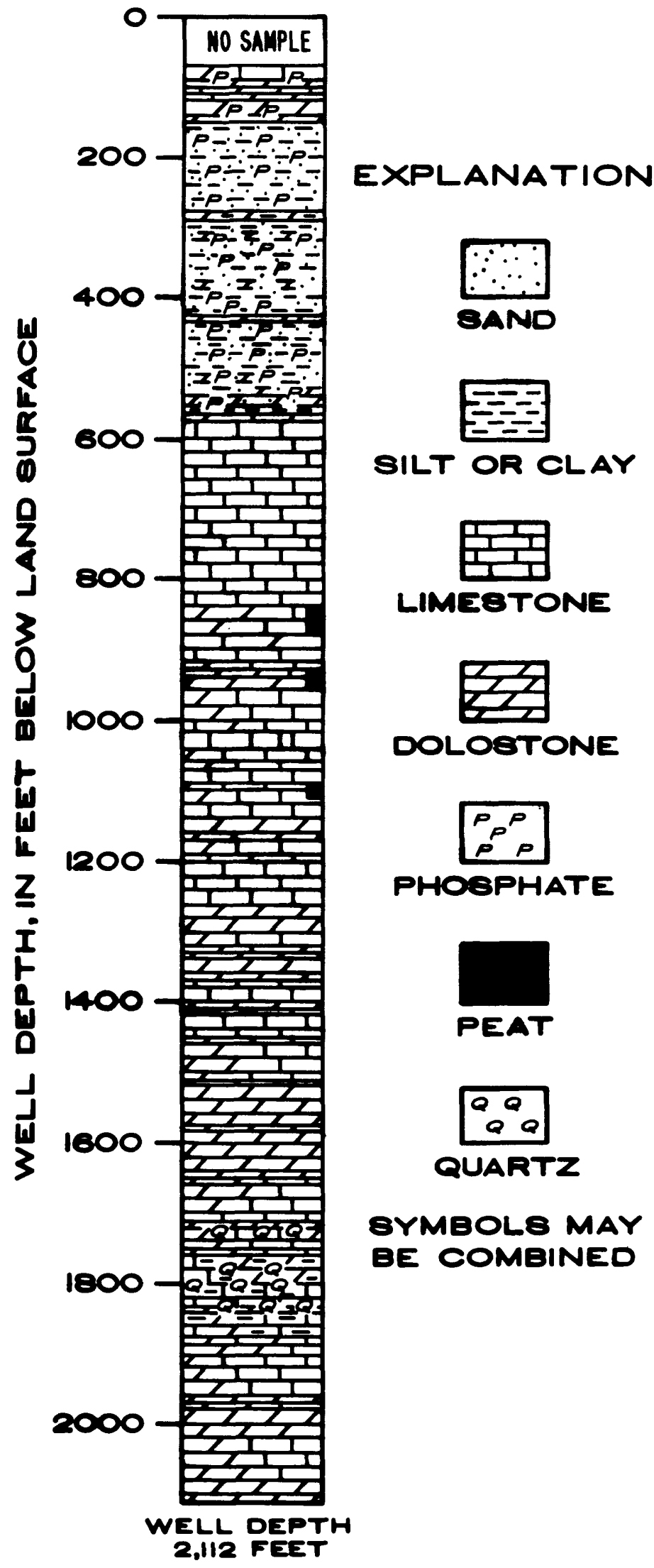

Figure 3.--Lithology at test well site. 

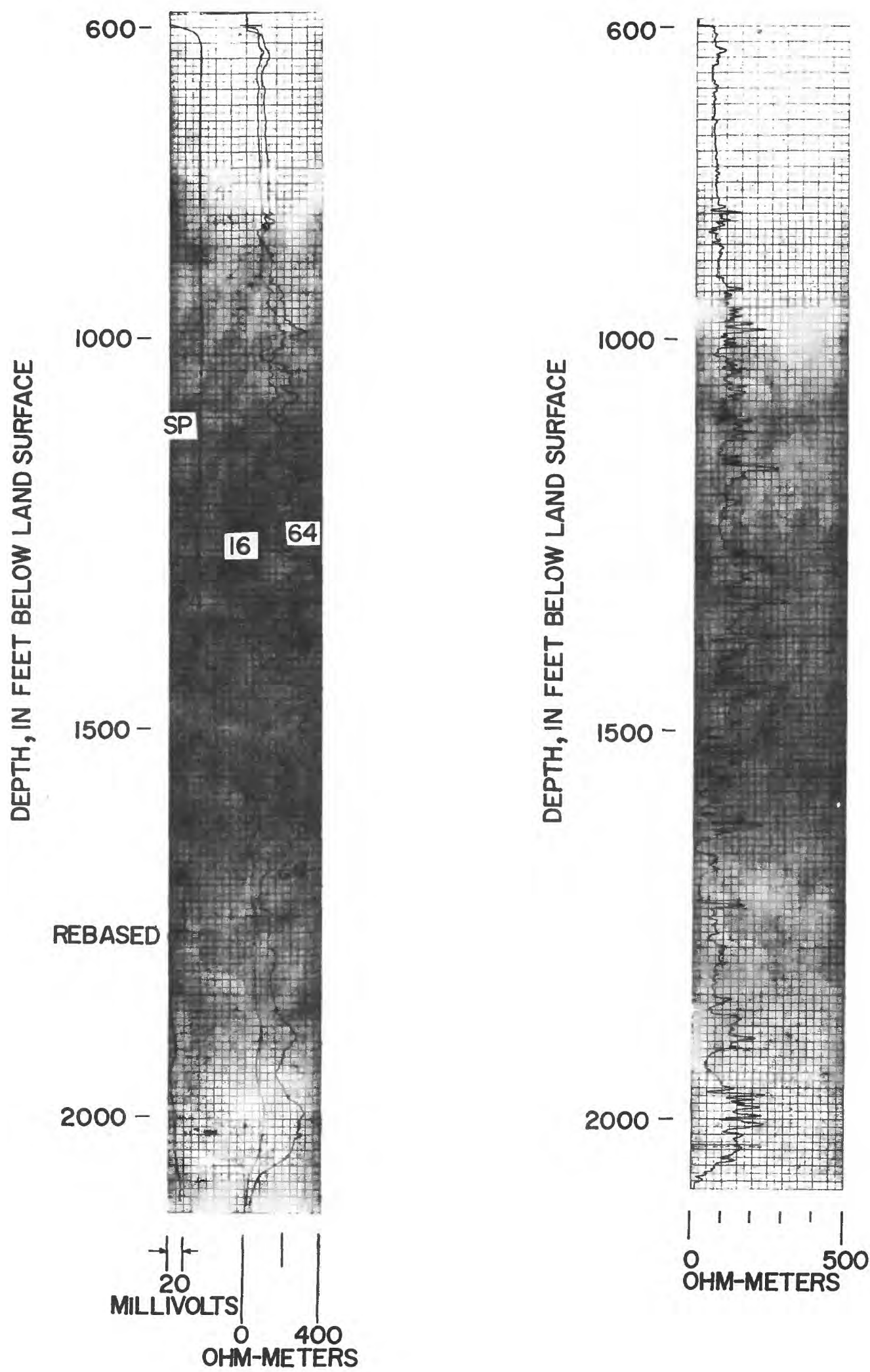

Figure 4.--Electric 1og; long and short normal resistivity, and spontaneous potential. 


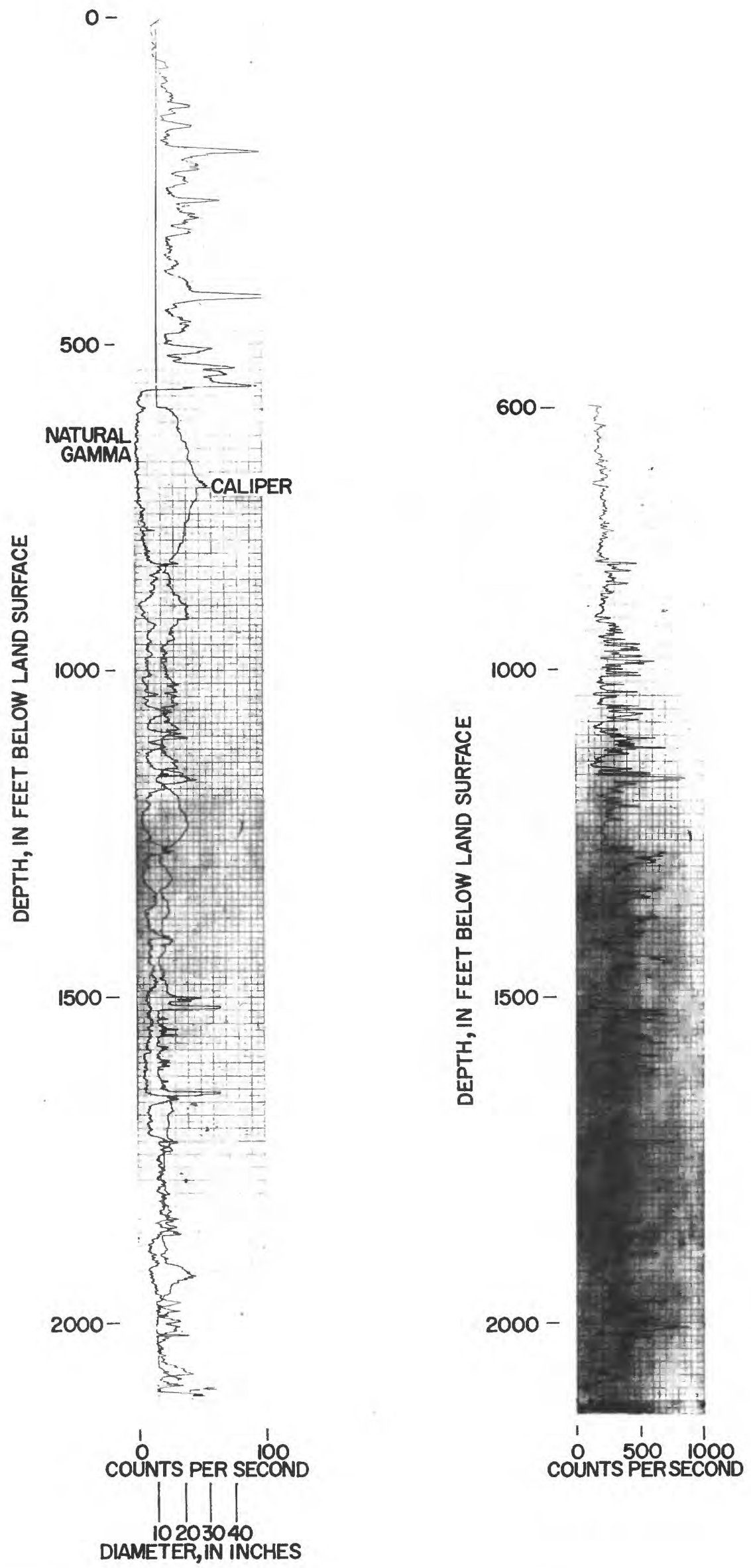

Figure 6.--Caliper and natural gamma 1 og. 


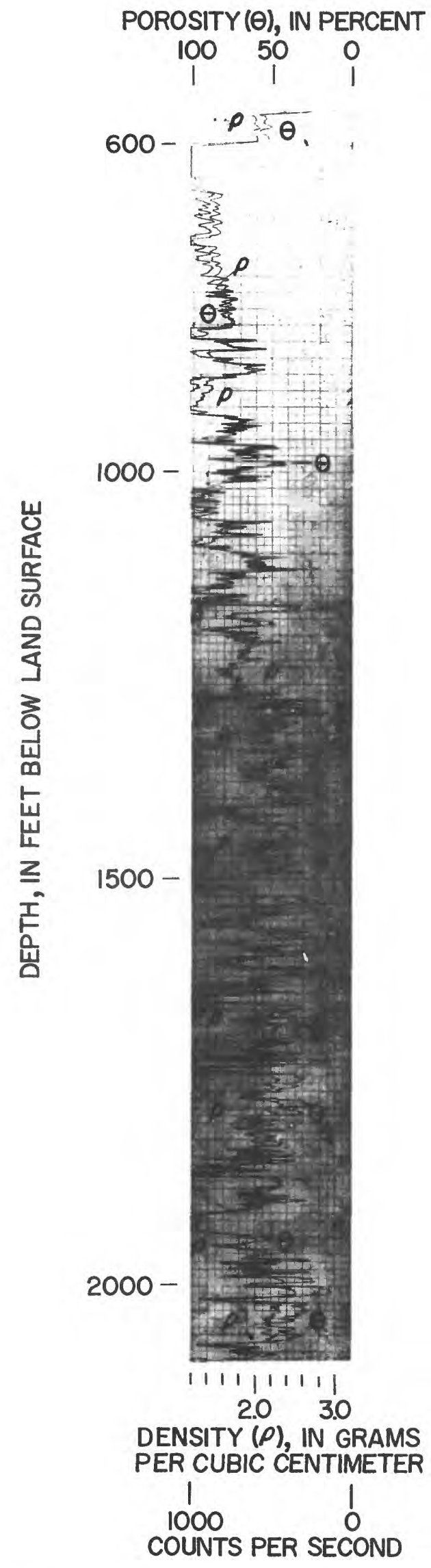

Figure 8.--Gamma-gamma density log.

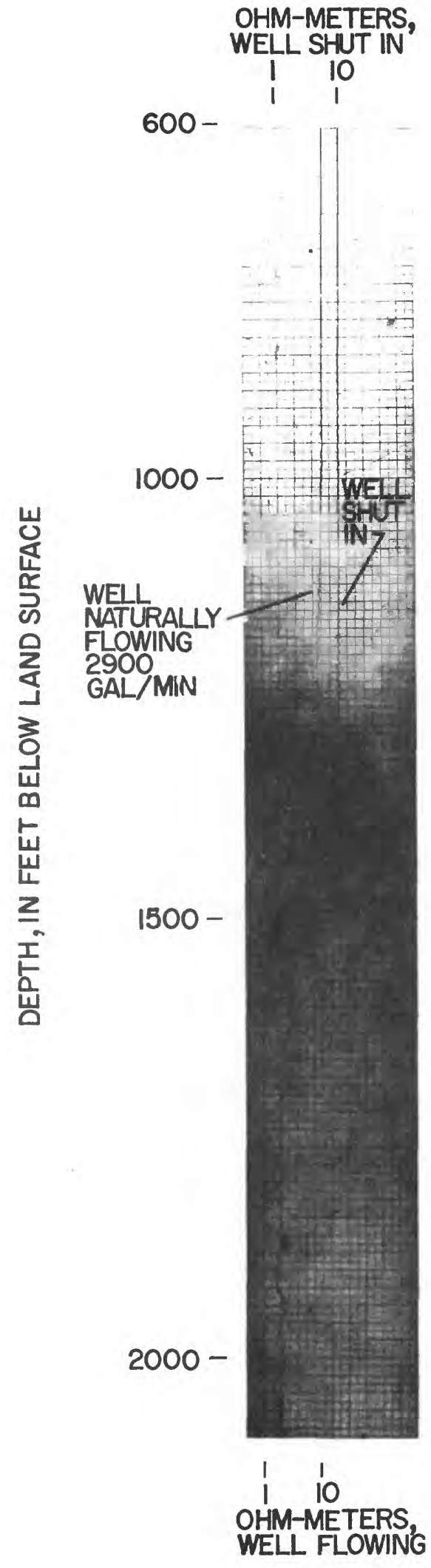

Figure 9.--Fluid resistivity log. 


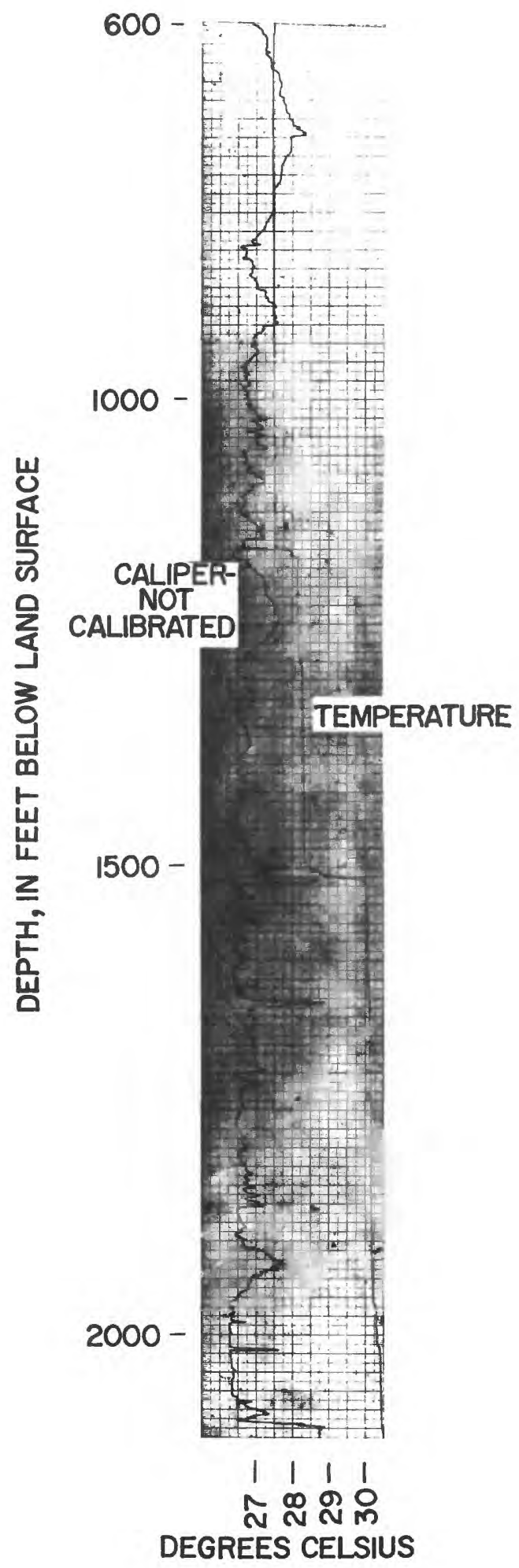

Figure 10.--Temperature $10 \mathrm{l}$.

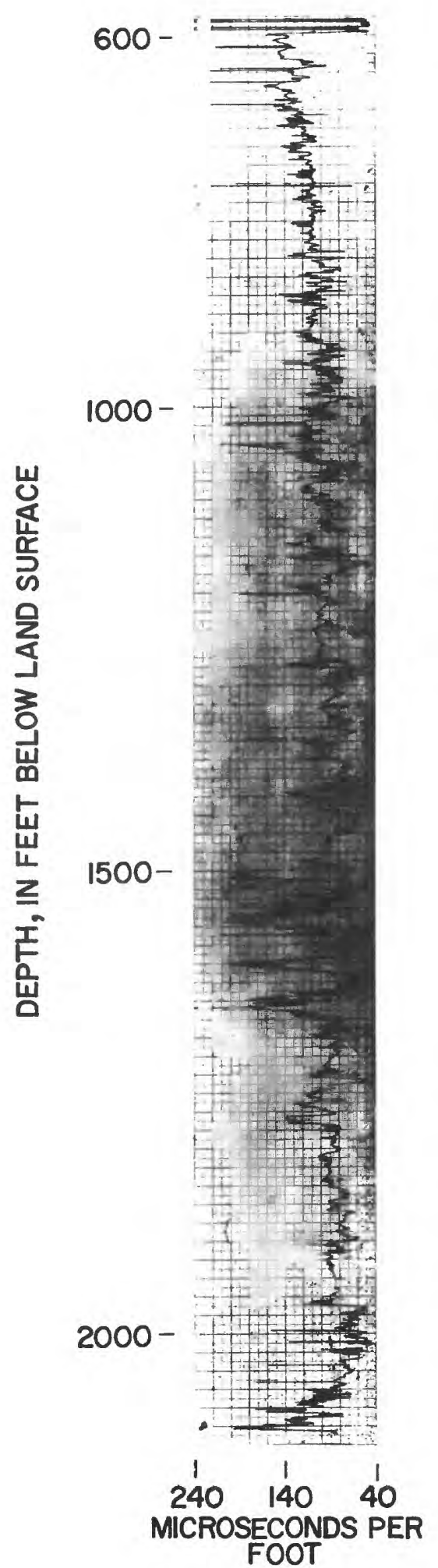

Figure 11.--Acoustic velocity $\log$. 
Table 2.--Water levels in drill stem and in annulus during drilling of test well

[Water level in feet above land surface]

\begin{tabular}{|c|c|c|c|}
\hline \multirow[b]{2}{*}{ Date } & \multirow{2}{*}{$\begin{array}{l}\text { Well depth } \\
\text { (ft) }\end{array}$} & \multicolumn{2}{|c|}{ Water leve1 } \\
\hline & & Drill stem & Annulus \\
\hline $11-16-82$ & 770 & 11.6 & 7.5 \\
\hline $11-17-82$ & 859 & 10.4 & 8.7 \\
\hline $11-24-82$ & 994 & 10.7 & 11.2 \\
\hline $11-26-82$ & 1,066 & 12.0 & 11.8 \\
\hline $11-29-82$ & 1,072 & 12.2 & 12.2 \\
\hline $11-30-82$ & 1,130 & 12.4 & 12.2 \\
\hline $12-01-82$ & 1,181 & 12.7 & 13.6 \\
\hline $12-07-82$ & 1,191 & 13.5 & 13.5 \\
\hline $12-08-82$ & 1,244 & 13.6 & 13.6 \\
\hline $12-10-82$ & 1,306 & 14.0 & 13.9 \\
\hline $12-13-82$ & 1,368 & 13.9 & 13.8 \\
\hline $12-14-82$ & 1,398 & 13.8 & 13.8 \\
\hline $12-16-82$ & 1,513 & 14.5 & 14.3 \\
\hline $12-17-82$ & 1,535 & 14.3 & 14.2 \\
\hline $12-20-82$ & 1,564 & 14.0 & 13.9 \\
\hline $12-27-82$ & 1,574 & -- & 14.9 \\
\hline $12-28-82$ & 1,574 & 15.0 & 14.9 \\
\hline $12-29-82$ & 1,600 & 14.9 & 14.8 \\
\hline $1-03-83$ & 1,628 & 14.9 & 14.9 \\
\hline $1-04-83$ & 1,638 & 13.7 & 14.7 \\
\hline $1-05-83$ & 1,651 & 13.2 & 14.8 \\
\hline $1-06-83$ & 1,678 & 13.2 & 14.7 \\
\hline $1-07-83$ & 1,714 & 13.1 & 14.5 \\
\hline $1-11-83$ & 1,721 & 13.5 & 14.9 \\
\hline $1-12-83$ & 1,724 & 13.2 & 14.7 \\
\hline $1-13-83$ & 1,735 & 13.3 & 14.6 \\
\hline $1-14-83$ & 1,741 & 13.2 & 14.4 \\
\hline $1-17-83$ & 1,762 & 13.0 & 14.1 \\
\hline $1-18-83$ & 1,778 & 13.2 & 14.2 \\
\hline $1-19-83$ & 1,803 & 12.8 & 14.0 \\
\hline $1-24-83$ & 1,828 & 12.6 & 13.8 \\
\hline $1-25-83$ & 1,836 & 13.0 & 14.0 \\
\hline $1-26-83$ & 1,845 & 13.2 & 14.2 \\
\hline $1-27-83$ & 1,855 & 13.4 & 14.4 \\
\hline $1-28-83$ & 1,859 & 13.1 & 14.3 \\
\hline $1-31-83$ & 1,877 & 13.1 & 14.2 \\
\hline
\end{tabular}


Table 2.--Water levels in drill stem and in annulus during drilling of test well--Continued

[Water level in feet above land surface]

\begin{tabular}{lccc}
\hline & $\begin{array}{c}\text { Weil depth } \\
\text { Date }\end{array}$ & \multicolumn{2}{c}{ Water level } \\
\cline { 3 - 4 } $2-01-83$ & 1,905 & 12.9 & Annulus \\
$2-03-83$ & 1,918 & 12.9 & 14.2 \\
$2-04-83$ & 1,937 & 12.2 & 14.2 \\
$2-07-83$ & 1,968 & 12.3 & 13.4 \\
$2-11-83$ & 1,978 & 13.1 & 14.0 \\
$2-15-83$ & 1,988 & 12.9 & 13.8 \\
$2-16-83$ & 2,009 & 12.1 & 13.7 \\
$2-17-83$ & 2,019 & 12.0 & 13.7 \\
$2-21-83$ & 2,076 & 12.7 & 13.8 \\
$2-22-83$ & 2,093 & 2.64 & 13.4 \\
$2-23-83$ & 2,095 & 1.67 & 13.8 \\
$2-24-83$ & 2,097 & 3.88 & 14.0 \\
$2-25-83$ & 2,099 & 1.18 & 14.0 \\
$2-28-83$ & 2,105 & 3.72 & 14.1 \\
$3-01-83$ & 2,107 & 1.17 & 14.4 \\
& & & \\
\hline
\end{tabular}




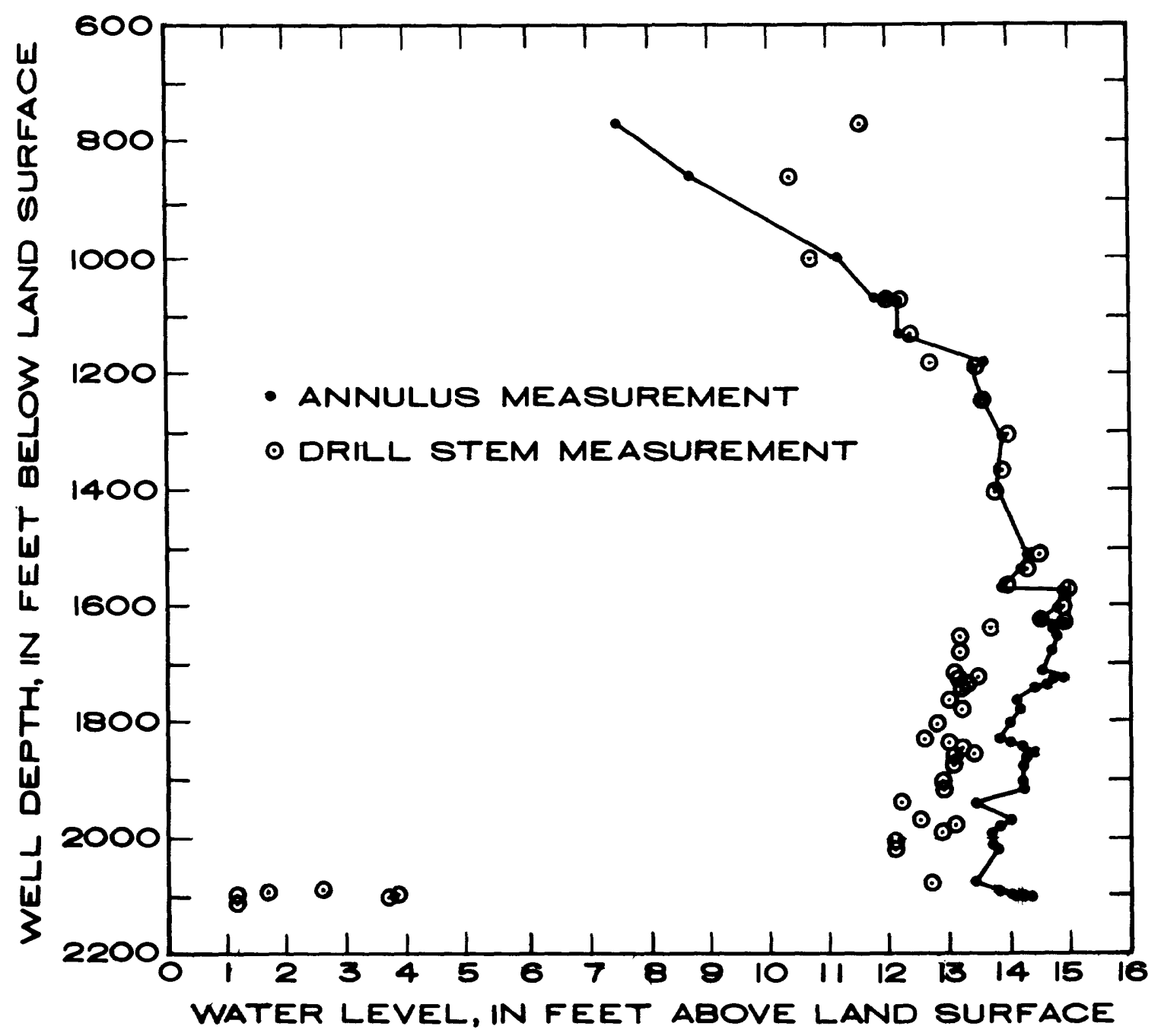

Figure 12.--Water levels in drill stem and in annulus during drilling of test well. 
For example, if a water-level measurement made in a well containing saline water with a density of $1.0084 \mathrm{~g} / \mathrm{cm}^{3}$ (a salinity of about $12,000 \mathrm{mg} / \mathrm{L}$ ) indicates a pressure head of about 5 feet above a datum such as the top of the well casing, and the saline water column is equal to the casing length of 2,050 feet, then $1_{s}=2,055$ feet and

$$
1_{f}=\frac{1.0084}{1.0000} \times 2,055 \text { feet }=2,072 \text { feet } .
$$

Therefore, the equivalent freshwater level would be 2,072 feet above the base of the casing or 22 feet above the top of the casing, or $17 \mathrm{feet}$ higher than the saline water level.

\section{Artesian Flow}

The flow of the test well with and without the drill stem in the hole was measured periodically during drilling (fig. 13). The flow (drill stem in hole) increased from about $500 \mathrm{gal} / \mathrm{min}$ at a depth of 1,150 feet to $1,500 \mathrm{gal} / \mathrm{min}$ at a depth of 1,616 feet. The maximum flow measured (without the drill stem in hole) was about 3,000 gal/min at a depth of 2,112 feet.

During drilling, down-hole traverses were made with a flow meter in the open-hole intervals of 600 to 1,191 feet, 600 to 1,570 feet, and 600 to 2,112 feet (figs. 14-16). Traverses were made with the well naturally flowing at $2,150 \mathrm{gal} / \mathrm{min}, 2,950 \mathrm{gal} / \mathrm{min}$, and $3,000 \mathrm{gal} / \mathrm{min}$, and with the well shut-in at the selected open-hole intervals, respectively.

\section{Water Chemistry}

Table 3 shows the specific conductance, chloride concentrations, and temperature of drill stem and annulus water samples as drilling progressed from 710 to 2,112 foot depths. Specific conductance ranged from 570 to 16,800 umhos $/ \mathrm{cm}$ at $25^{\circ} \mathrm{C}$ in the drill stem samples and from 775 to 1,280 umhos/cm in the annulus samples (fig. 17). Chloride concentrations of drill stem samples ranged from 22 to $5,450 \mathrm{mg} / \mathrm{L}$ and 85 to $250 \mathrm{mg} / \mathrm{L}$ for annulus samples. Chloride concentrations of drill stem samples ranged from 22 to $172 \mathrm{mg} / \mathrm{L}$ from a depth of 711 to 1,616 feet and then increased to $818 \mathrm{mg} / \mathrm{L}$ at 1,648 feet. Chloride concentrations ranged from 345 to $790 \mathrm{mg} / \mathrm{L}$ to a depth of 2,071 feet. Below 2,071 feet chloride concentration ranged from $2,525 \mathrm{mg} / \mathrm{L}$ to a maximum of $5,450 \mathrm{mg} / \mathrm{L}$ at 2,107 feet (fig. 18). The water temperature from the drill stem ranged from $25^{\circ} \mathrm{C}$ to $28^{\circ} \mathrm{C}$, generally increasing with depth. 


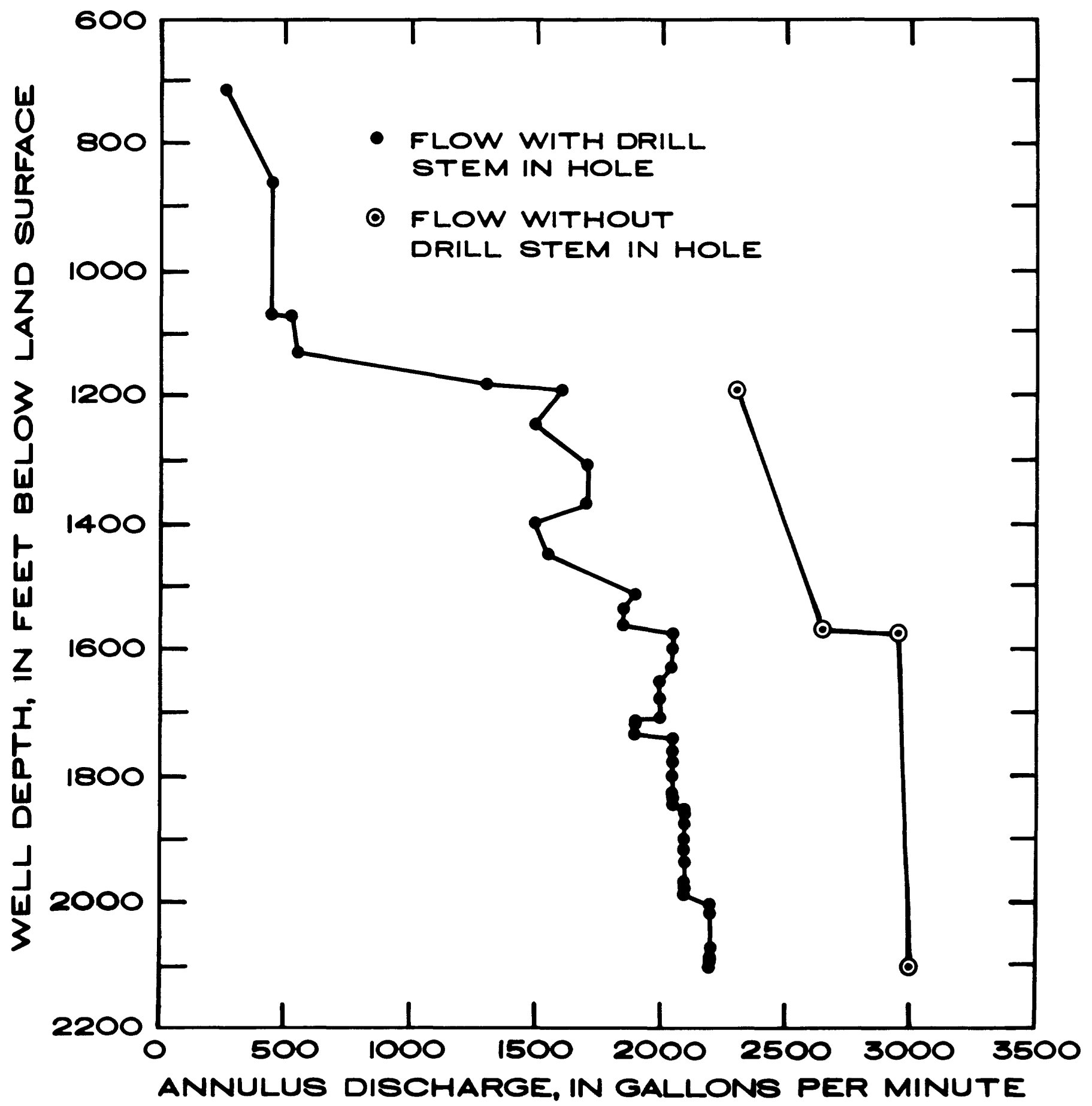

Figure 13.--Artesian flow of test well during drilling. 


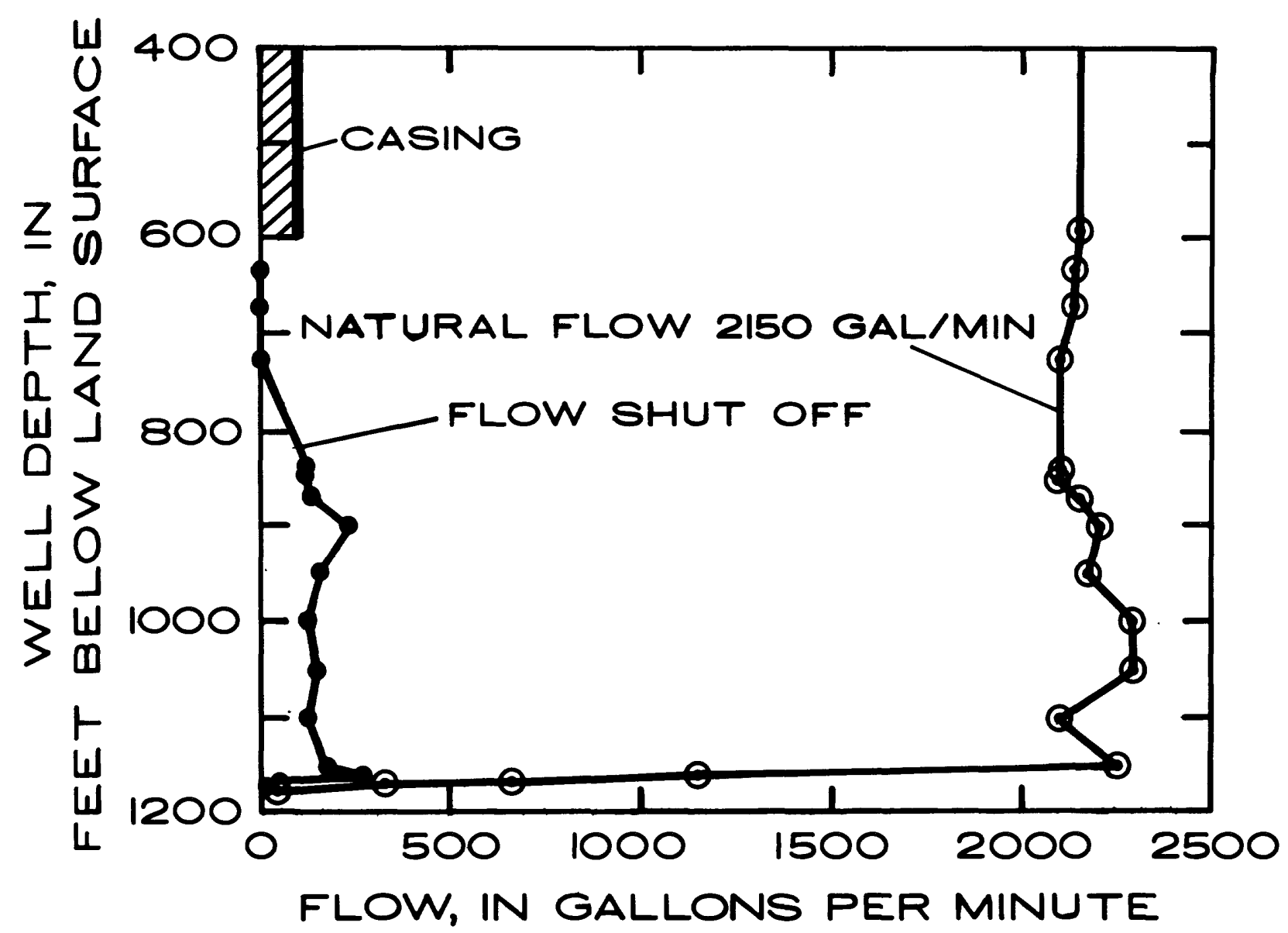

Figure 14.--Flow-meter traverses in test we11, open-hole interval 600 to 1,191 feet below land surface. 


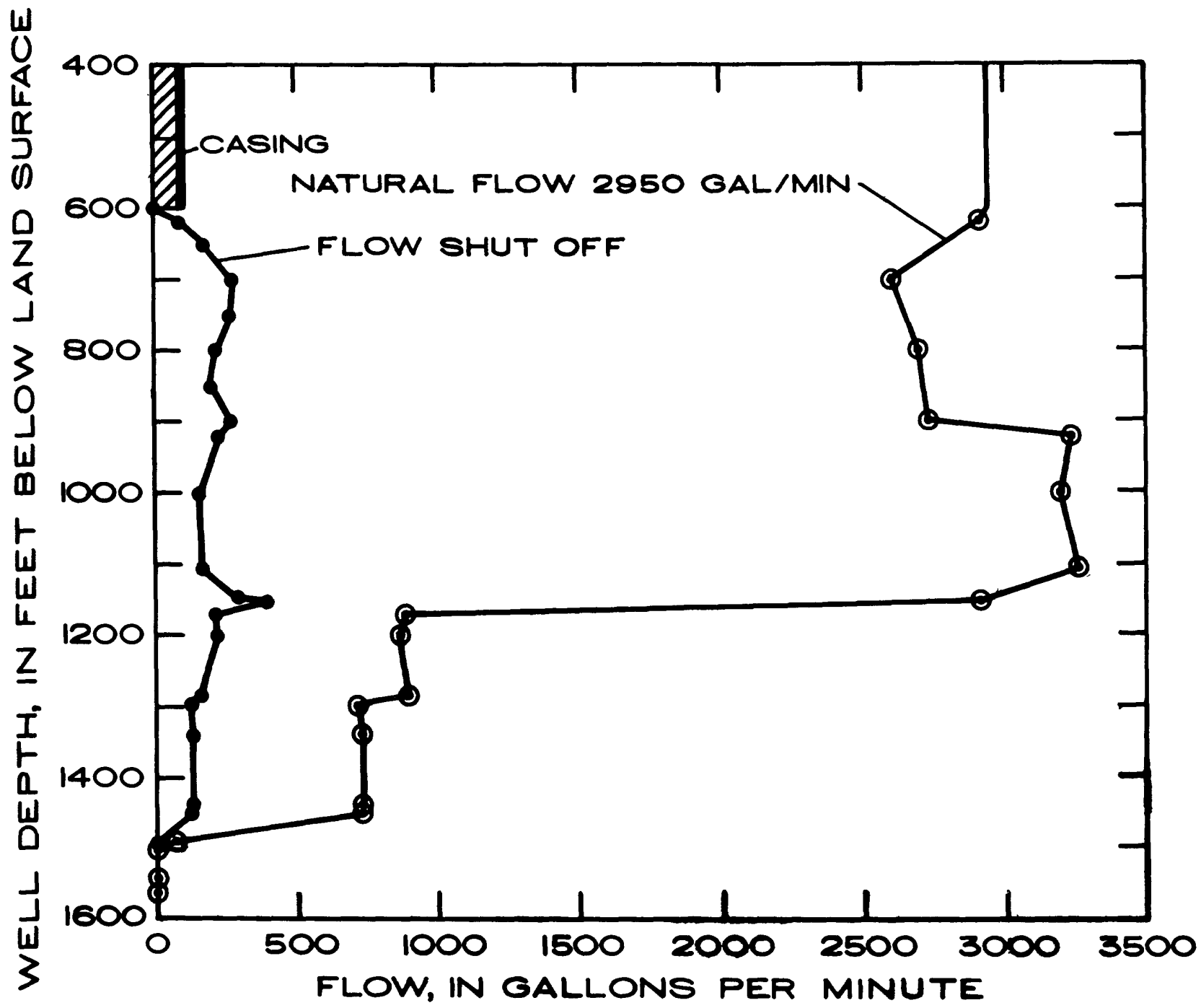

Figure 15.--Flow-meter traverses in test we11, open-hole interval 600 to 1,570 feet below land surface. 


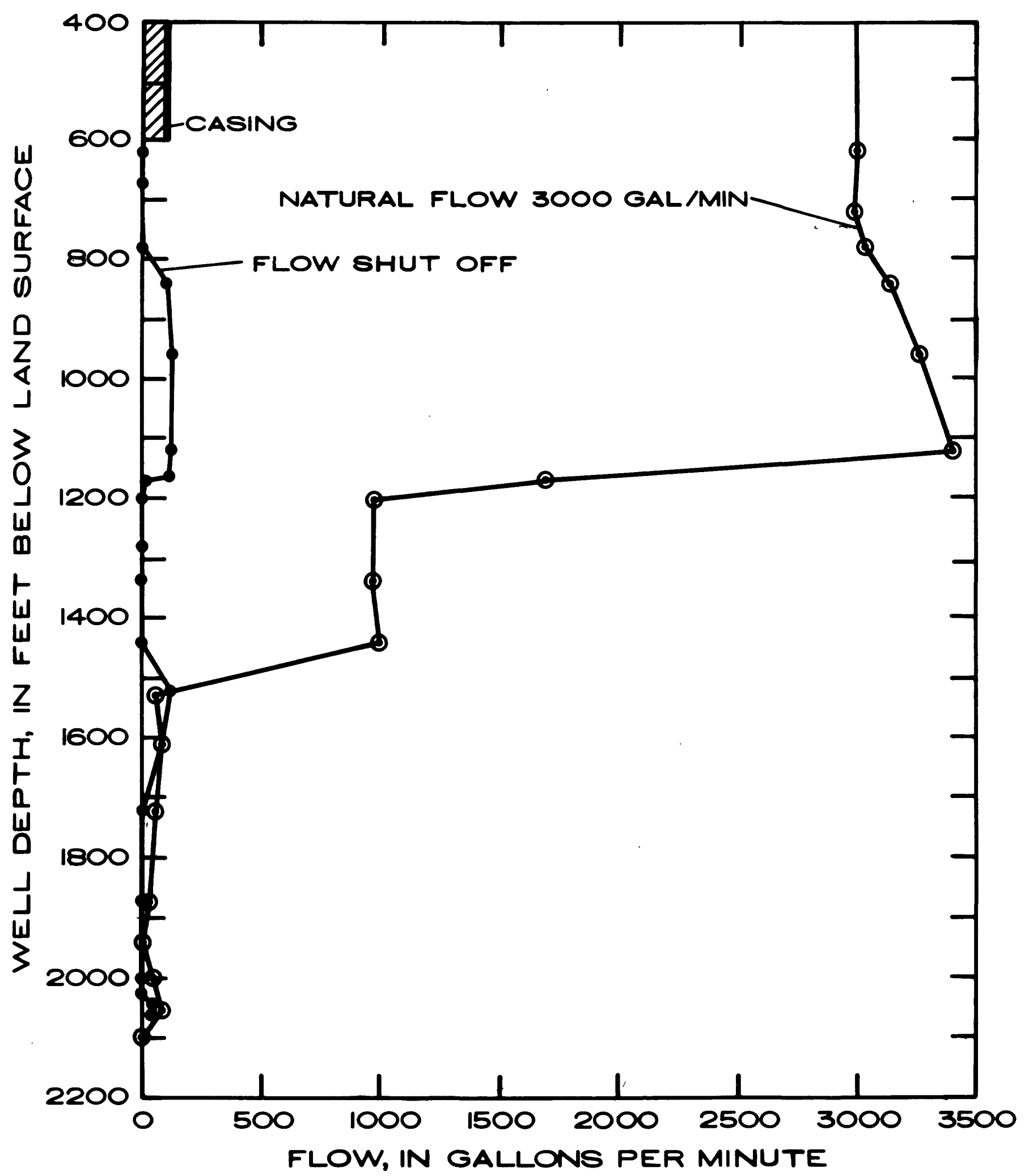

Figure 16.--Flow-meter traverses in test well, open-hole interval 600 to 2,112 feet below land surface. 
Table 3.--Specific conductance, chloride concentrations, and temperature of water obtained from the drill stem and the annulus as test well was drilled from 710 to 2,112 feet

\begin{tabular}{|c|c|c|c|c|c|c|}
\hline \multirow[b]{2}{*}{$\begin{array}{c}\text { Depth } \\
(\mathrm{ft})\end{array}$} & \multicolumn{3}{|c|}{ Drill stem } & \multicolumn{3}{|c|}{ Annulus } \\
\hline & $\begin{array}{c}\text { Specific } \\
\text { conductance } \\
\text { (umhos } / \mathrm{cm} \\
\text { at } 25^{\circ} \mathrm{C} \text { ) }\end{array}$ & $\begin{array}{c}\text { Chloride } \\
(\mathrm{mg} / \mathrm{L})\end{array}$ & $\begin{array}{c}\text { Temperature } \\
\left({ }^{\circ} \mathrm{C}\right)\end{array}$ & $\begin{array}{c}\text { Specific } \\
\text { conductance } \\
(\text { umhos } / \mathrm{cm} \\
\text { at } 25^{\circ} \mathrm{C} \text { ) }\end{array}$ & $\begin{array}{c}\text { Chloride } \\
(\mathrm{mg} / \mathrm{L})\end{array}$ & $\begin{array}{c}\text { Temperatur } \epsilon \\
\left({ }^{\circ} \mathrm{C}\right)\end{array}$ \\
\hline 710 & -- & -- & -- & 925 & 120 & 24.0 \\
\hline 711 & 910 & 110 & 25.0 & 910 & 115 & 24.5 \\
\hline 741 & 845 & 110 & 25.0 & 860 & 92 & 25.0 \\
\hline 770 & 765 & 88 & 25.0 & 795 & 98 & 25.0 \\
\hline 799 & 765 & 75 & 25.0 & 830 & 98 & 25.0 \\
\hline 830 & 740 & 68 & 25.0 & 820 & 98 & 25.0 \\
\hline 859 & 875 & 110 & 25.5 & 835 & 95 & 25.0 \\
\hline 888 & 970 & 145 & 25.5 & 848 & 100 & 25.5 \\
\hline 917 & 1,060 & 172 & 25.5 & 838 & 92 & 25.5 \\
\hline 956 & 950 & 140 & 26.0 & 800 & 85 & 25.5 \\
\hline 984 & 1,000 & 148 & 25.5 & 860 & 105 & 25.5 \\
\hline 994 & 1,025 & 150 & 26.0 & 800 & 90 & 25.5 \\
\hline 1,014 & 975 & 132 & 26.0 & 925 & 115 & 25.5 \\
\hline 1,043 & 900 & 118 & 26.0 & 855 & 98 & 26.0 \\
\hline 1,072 & 865 & 112 & 26.0 & 850 & 100 & 25.5 \\
\hline 1,101 & 760 & 80 & 25.5 & 830 & 98 & 25.5 \\
\hline 1,130 & 770 & 78 & 25.5 & 830 & 100 & 25.0 \\
\hline 1,157 & 1,000 & 100 & 27.0 & 850 & -- & 27.0 \\
\hline 1,161 & 1,000 & 150 & 27.0 & 980 & 140 & 27.0 \\
\hline 1,191 & 990 & 146 & 27.0 & 990 & -- & 27.0 \\
\hline 1,213 & 1,000 & 145 & 27.0 & 1,000 & 146 & 27.0 \\
\hline 1,244 & 975 & 144 & 27.0 & 1,000 & 145 & 27.0 \\
\hline 1,274 & 980 & 140 & 27.0 & 1,000 & 145 & 27.0 \\
\hline 1,306 & 575 & 25 & 27.0 & 1,010 & 148 & 27.0 \\
\hline 1,337 & 575 & 25 & 27.0 & 980 & 140 & 27.0 \\
\hline 1,368 & 575 & 27 & 27.0 & 975 & 140 & 27.0 \\
\hline 1,398 & 575 & 24 & 27.0 & 1,000 & 140 & 27.0 \\
\hline 1,430 & 575 & 23 & 27.0 & 1,000 & 138 & 27.0 \\
\hline 1,461 & 570 & 23 & 27.0 & 985 & 140 & 27.0 \\
\hline 1,492 & 570 & 22 & 27.0 & 985 & 141 & 27.0 \\
\hline 1,523 & 580 & 29 & 27.0 & 875 & 108 & 27.0 \\
\hline 1,554 & 625 & 29 & 27.5 & 925 & 105 & 27.5 \\
\hline 1,584 & 600 & 55 & 27.5 & 775 & 124 & 27.5 \\
\hline 1,616 & 610 & 45 & 27.5 & 825 & 114 & 27.5 \\
\hline 1,638 & 1,450 & 320 & 27.5 & -- & - & - \\
\hline 1,648 & 3,300 & 818 & 27.5 & 825 & 102 & 27.5 \\
\hline 1,678 & 3,200 & 718 & 27.5 & 850 & 110 & 27.5 \\
\hline 1,710 & 2,900 & 706 & 27.5 & 850 & 114 & 27.5 \\
\hline 1,741 & 2,700 & 630 & 28.0 & 900 & 110 & 28.0 \\
\hline 1,772 & 2,800 & 680 & 27.5 & 850 & 107 & 27.5 \\
\hline 1,804 & 2,550 & 620 & 27.5 & 860 & 114 & 27.5 \\
\hline 1,833 & 2,800 & 700 & 27.5 & 860 & 122 & 27.5 \\
\hline 1,863 & 2,700 & 700 & 27.5 & 875 & 122 & 27.5 \\
\hline 1,894 & 2,800 & 736 & 27.5 & 820 & 108 & 27.5 \\
\hline 1,915 & 2,400 & 620 & 27.5 & -- & -- & -- \\
\hline 1,925 & 2,800 & 720 & 27.5 & 850 & 112 & 27.5 \\
\hline
\end{tabular}


Table 3.--Specific conductance, chloride concentrations, and temperature of water obtained from the drill stem and the annulus as test well was drilled from 710 to 2,112 feet--Continued

\begin{tabular}{|c|c|c|c|c|c|c|}
\hline \multirow[b]{2}{*}{$\begin{array}{c}\text { Depth } \\
\text { (ft) }\end{array}$} & \multicolumn{3}{|c|}{ Drill stem } & \multicolumn{3}{|c|}{ Annulus } \\
\hline & $\begin{array}{c}\text { Specific } \\
\text { conductance } \\
\text { (umhos } / \mathrm{cm} \\
\text { at } 25^{\circ} \mathrm{C} \text { ) }\end{array}$ & $\begin{array}{c}\text { Chloride } \\
(\mathrm{mg} / \mathrm{L})\end{array}$ & $\begin{array}{c}\text { Temperature } \\
\left({ }^{\circ} \mathrm{C}\right)\end{array}$ & $\begin{array}{c}\text { Specific } \\
\text { conductance } \\
(\text { umhos } / \mathrm{cm} \\
\text { at } 25^{\circ} \mathrm{C} \text { ) }\end{array}$ & $\begin{array}{c}\text { Chloride } \\
(\mathrm{mg} / \mathrm{L})\end{array}$ & $\begin{array}{c}\text { Temperature } \\
\left({ }^{\circ} \mathrm{C}\right)\end{array}$ \\
\hline 1,937 & 1,750 & 345 & 27.5 & -- & -- & --- \\
\hline 1,947 & 3,200 & 790 & 27.5 & -- & -- & -- \\
\hline 1,957 & 3,100 & 760 & 27.5 & 870 & 115 & 27.5 \\
\hline 1,968 & 2,250 & 425 & 27.5 & -- & -- & -- \\
\hline 1,978 & 2,100 & 500 & 27.5 & -- & -- & -- \\
\hline 1,988 & 2,000 & 420 & 27.5 & 950 & 135 & 27.5 \\
\hline 1,999 & 1,825 & 430 & 27.5 & -- & -- & -- \\
\hline 2,009 & 2,100 & 478 & 27.5 & -- & -- & -- \\
\hline 2,019 & 2,300 & 530 & 27.5 & 900 & 130 & 27.5 \\
\hline 2,031 & 2,750 & 690 & 27.5 & -- & -- & -- \\
\hline 2,041 & 2,400 & 580 & 27.5 & -- & -- & -- \\
\hline 2,051 & 2,750 & 680 & 27.5 & 970 & 158 & 27.5 \\
\hline 2,061 & 2,500 & 600 & 27.5 & -- & - & -- \\
\hline 2,071 & 2,500 & 586 & 27.5 & -- & -- & -- \\
\hline 2,081 & 8,800 & 3,360 & 28.0 & 1,280 & 250 & 28.0 \\
\hline 2,086 & 9,400 & 2,910 & 28.0 & -- & -- & -- \\
\hline 2,092 & 8,450 & 2,525 & 28.0 & -- & -- & -- \\
\hline 2,095 & 15,400 & 4,830 & 28.0 & 1,200 & 186 & 28.0 \\
\hline 2,096 & 12,600 & 3,960 & 28.0 & -- & -- & -- \\
\hline 2,097 & 13,000 & 4,200 & 28.0 & -- & -- & -- \\
\hline 2,102 & 15,700 & 4,880 & 28.0 & -- & -- & -- \\
\hline 2,107 & 16,800 & 5,450 & 28.0 & -- & -- & -- \\
\hline 2,112 & 16,800 & 5,370 & 28.0 & 950 & -- & 27.5 \\
\hline
\end{tabular}




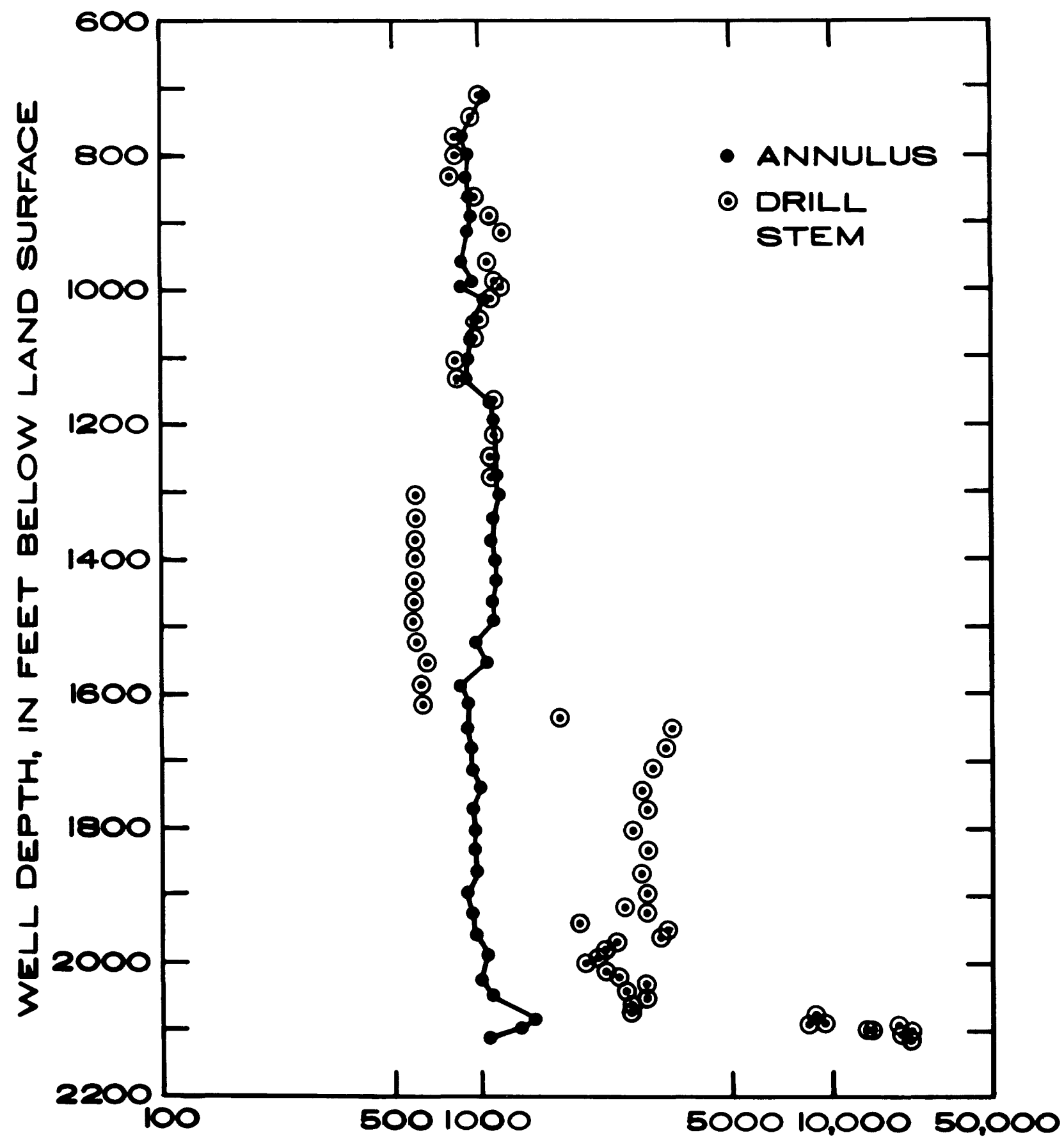

BPECIFIC CONDUCTANCE, IN MICROMHOS PER CENTIMETER AT 25 DEGREES CELSIUS

Figure 17.--Specific conductance of water obtained from the drill stem and the annulus as the test well was drilled from 710 to 2,112 feet. 


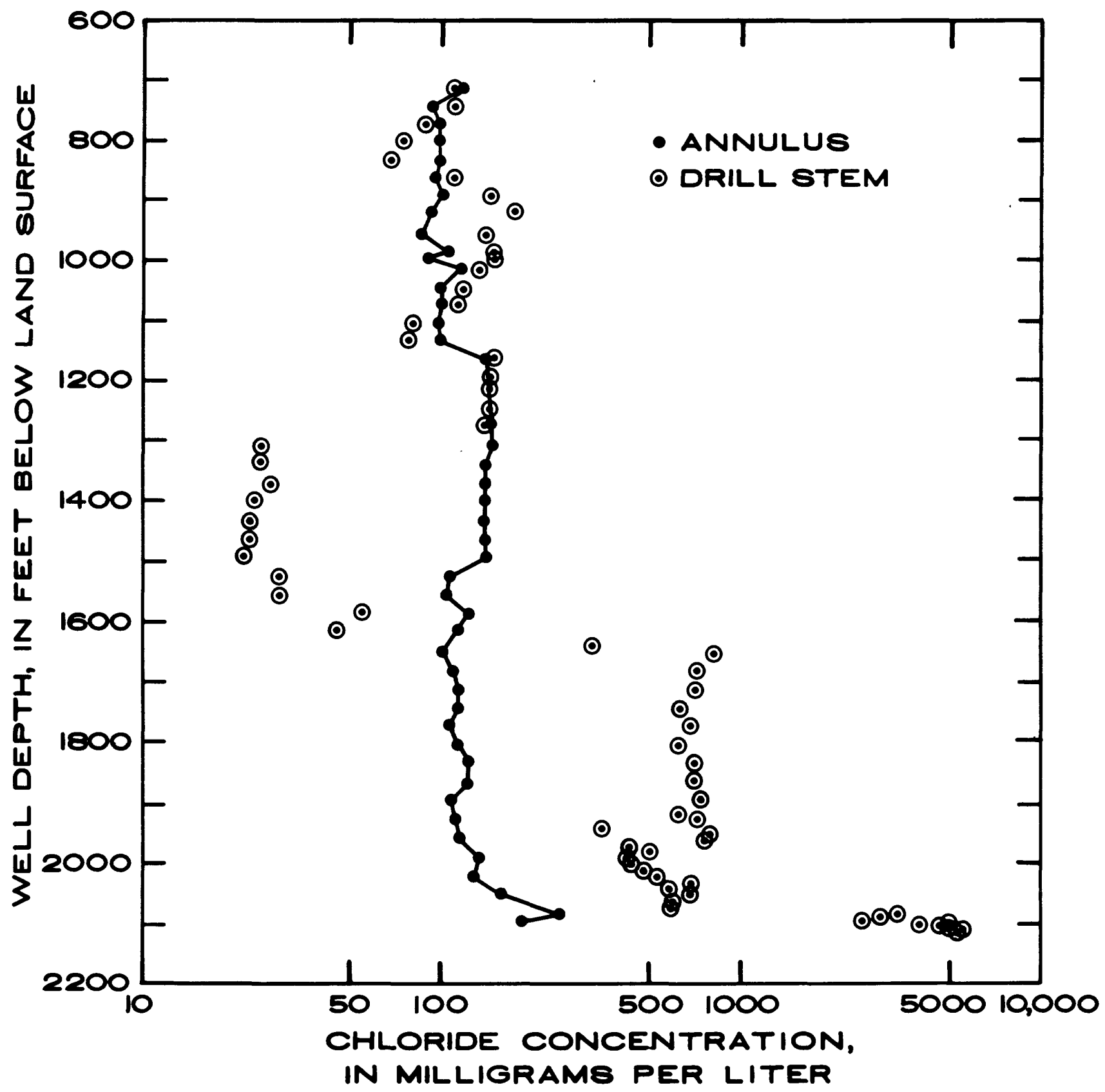

Figure 18.--Chloride concentrations of water obtained from the drill stem and the annulus as the test well was drilled from 710 to 2,112 feet. 


\section{SELECTED REFERENCES}

Brown, D. P., Johnson, R. A., and Baker, J. S., 1984, Hydrogeologic data from a test well at Kathryn Abbey Hanna Park, City of Jacksonville, Florida: U.S. Geological Survey Open-File Report 84-143, 48 p.

Cooper, H. H., Jr., Kohout, F. A., Henry, H. R., and Glover, R. E., 1964, Sea water in coastal aquifers: U.S. Geological Survey Water-Supply Paper 1613-C, p. C1-C84.

Lohman, S. W., and others, 1972, Definitions of selected ground-water terms-revisions and conceptual refinements: U.S. Geological Survey Water-Supply Paper 1988, 21 p.

Miller, J. A., 1984, Hydrogeologic framework of the Floridan aquifer system in Florida and in parts of Georgia, South Carolina, and Alabama: U.S. Geological Survey Professional Paper 1403-B (in press). 